Supporting Information for

\title{
Pore environment effects on catalytic cyclohexane oxidation in expanded $\mathrm{Fe}_{2}(\mathrm{dobdc})$ analogues
}

\author{
Dianne J. Xiao, ${ }^{1}$ Julia Oktawiec, ${ }^{1}$ Phillip J. Milner, ${ }^{1}$ and Jeffrey R. Long*,1,2,3 \\ ${ }^{1}$ Department of Chemistry, University of California, Berkeley, California 94720, United States \\ ${ }^{2}$ Department of Chemical and Biomolecular Engineering, University of California, Berkeley, California 94720, \\ United States \\ ${ }^{3}$ Materials Sciences Division, Lawrence Berkeley National Laboratory, Berkeley, California 94720, United States \\ * Correspondence to: jrlong@berkeley.edu
}

Table of contents

1. General considerations

2. Control experiments

3. Ligand syntheses

4. Powder X-ray diffraction data collection and analysis

5. Mössbauer data collection and analysis

6. Kinetic isotope effect determination

7. Supplemental Tables

8. Supplemental Figures

9. References
Page

S2

S3

S4-S10

$\mathrm{S} 11$

$\mathrm{S} 12$

$\mathrm{S} 13$

S14-S18

S19-S27

S28 


\section{General considerations.}

Unless otherwise noted, all procedures were performed under an $\mathrm{N}_{2}$ atmosphere using standard glove box or Schlenk techniques. $N, N$-dimethylformamide (DMF) was dried using a commercial solvent purification system designed by JC Meyer Solvent Systems and then stored over $4 \AA$ molecular sieves. Anhydrous methanol was purchased from commercial vendors, further dried over $3 \AA$ sieves for $24 \mathrm{~h}$, and deoxygenated prior to being transferred to an inert atmosphere glove box, where it was stored over $3 \AA$ molecular sieves. Cyclohexane, cyclohexane- $\mathrm{d}_{12}$, and acetonitrile- $\mathrm{d}_{3}$ were similarly dried over $3 \AA$ sieves, deoxygenated, and stored over $3 \AA$ sieves in an inert atmosphere glovebox before use. Cyclohexane- $d_{12}(\geq 99.6$ atom \% D) was purchased from Sigma Aldrich. The oxidant $t \mathrm{BuSO}_{2} \mathrm{PhIO}{ }^{1}$ and the frameworks $\mathrm{Fe}_{2}$ (dobdc) ${ }^{2}$ and $\mathrm{Fe}_{2}(\text { dobpdc) })^{3}$ were synthesized according to previously published procedures.

$\mathrm{C}, \mathrm{H}$, and $\mathrm{N}$ analyses were obtained from the Microanalytical Laboratory at the University of California, Berkeley. ${ }^{1} \mathrm{H}-\mathrm{NMR}$ spectra were obtained using a Bruker AVB-400 instrument. 


\section{Control experiments.}

Filtration control experiments: Post-catalysis (see general catalysis conditions in the experimental section), $\mathrm{Fe}_{2}\left(\right.$ dotpdc $\left.^{\mathrm{R}}\right)$ was removed by filtration and additional $t \mathrm{BuSO}_{2} \mathrm{PhIO}(10$ $\mathrm{mg}$ ) was added to the filtrate. The resulting mixture was stirred for $1.5 \mathrm{~h}$ and the solution analyzed by ${ }^{1} \mathrm{H}$ NMR. No additional cyclohexane oxidation products were observed after framework removal.

Control experiment with $\mathrm{FeCl}_{2}$ and ligand: A mixture of $\mathrm{FeCl}_{2}(2.3 \mathrm{mg}, 0.019 \mathrm{mmol})$ and $\mathrm{H}_{4}$ (dotpdc) (3.2 mg, $0.0093 \mathrm{mmol}$ ) was dissolved in $\mathrm{CD}_{3} \mathrm{CN}$ (1 mL) and exposed to cyclohexane $(0.30 \mathrm{~mL}, 2.8 \mathrm{mmol})$ and $t \mathrm{BuSO}_{2} \mathrm{PhIO}(25 \mathrm{mg}, 0.073 \mathrm{mmol}$, partially dissolved slurry in $1 \mathrm{~mL}$ $\mathrm{CD}_{3} \mathrm{CN}$ ). After vigorously stirring at room temperature for $1.5 \mathrm{~h}$, the mixture was filtered through alumina and the filtrate was analyzed by ${ }^{1} \mathrm{H}$ NMR. No oxidized cyclohexane products (cyclohexanol, cyclohexanone) were observed.

Digestion of $\mathrm{Fe}_{2}\left(\operatorname{dotpdc}^{R}\right)$ : To make sure the framework ligands are not oxidized over the course of the reaction, particularly in the case of $\mathrm{Fe}_{2}\left(\operatorname{dotpdc}{ }^{\mathrm{CH} 3}\right)$ and $\mathrm{Fe}_{2}\left(\operatorname{dotpdc}^{t \mathrm{Bu}}\right)$, digestion experiments were performed post-catalysis. Specifically, after a cyclohexane oxidation run, $\mathrm{Fe}_{2}\left(\operatorname{dotpdc}^{\mathrm{R}}\right)(5.0 \mathrm{mg})$ was filtered, washed with acetonitrile, and stirred for $30 \mathrm{~min}$ in the presence of $3 \mathrm{M}$ aqueous $\mathrm{HCl}(2 \mathrm{~mL})$. This treatment dissolves the $\mathrm{Fe}^{3+}$ cations but leaves the water-insoluble terphenyl ligand behind as a precipitate. The precipitate was filtered, washed with $\mathrm{H}_{2} \mathrm{O}$, dried, and dissolved in DMSO- $\mathrm{d}_{6}$. Analysis by ${ }^{1} \mathrm{H}$ NMR shows that the ligand stays intact with no evidence of oxidation (e.g. methyl group hydroxylation) (see Figure S7 and S8). 


\section{Ligand syntheses.}

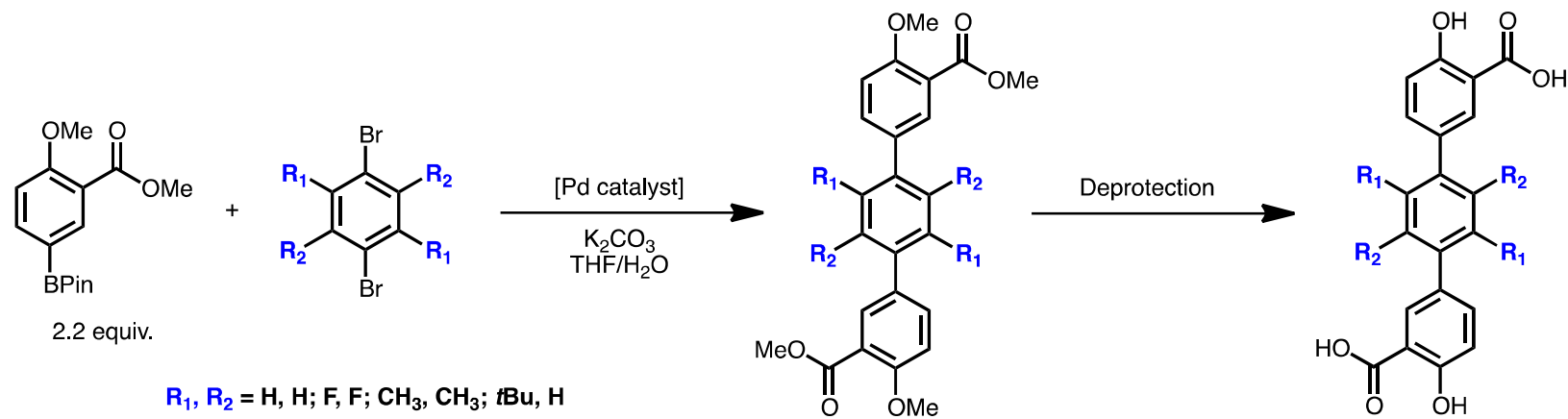

Scheme 1. General synthetic route to making $\mathrm{H}_{4}(\operatorname{dotpdc}), \mathrm{H}_{4}\left(\operatorname{dotpdc}^{\mathrm{F}}\right), \mathrm{H}_{4}\left(\operatorname{dotpdc}^{\mathrm{CH} 3}\right)$, and $\mathrm{H}_{4}\left(\operatorname{dotpdc}^{t \mathrm{Bu}}\right)$. Note that while the first three ligands are made following identical procedures (see below for details), a slightly different palladium catalyst and deprotection conditions were used for $\mathrm{H}_{4}\left(\operatorname{dotpdc}^{t \mathrm{Bu}}\right)$ due to the increased steric bulk of the tert-butyl groups and their sensitivity to harsh acidic conditions.

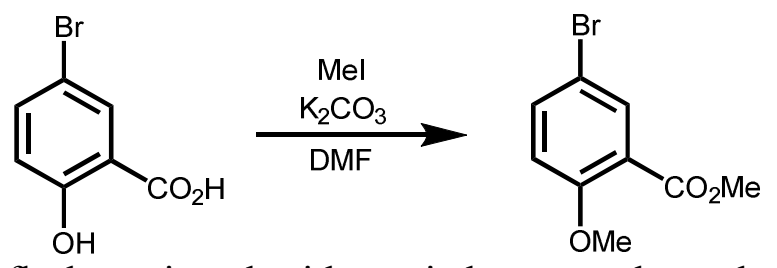

A $500 \mathrm{~mL}$ roundbottom flask equipped with a stir bar was charged with potassium carbonate (62.1 g, $450 \mathrm{mmol}, 5.0$ eq.) and 5-bromosalicylic acid (19.6 g, $90.0 \mathrm{mmol}, 1.00$ eq.). DMF (500 $\mathrm{mL}$ ) was added, and the roundbottom flask was placed in a cold water bath. Iodomethane (16.8 $\mathrm{mL}, 270 \mathrm{mmol}, 3.00$ eq.) was added slowly, and the reaction mixture was allowed to stir vigorously at room temperature for $14 \mathrm{~h}$. The reaction mixture was poured into ice water $(2.5 \mathrm{~L})$ and vigorously stirred for 10 minutes. The resulting non-homogeneous mixture was filtered to yield methyl 5-bromo-2-methoxybenzoate ( $16.6 \mathrm{~g}, 75 \%$ yield) as an off-white solid. ${ }^{1} \mathrm{H}$ NMR $\left(400 \mathrm{MHz}, \mathrm{CDCl}_{3}\right): \delta 7.86(\mathrm{~d}, \mathrm{~J}=3 \mathrm{~Hz}, 1 \mathrm{H}), 7.51(\mathrm{dd}, \mathrm{J}=9,3 \mathrm{~Hz}, 1 \mathrm{H}), 6.82(\mathrm{~d}, \mathrm{~J}=9 \mathrm{~Hz}, 1 \mathrm{H})$, $3.85(\mathrm{~s}, 3 \mathrm{H}), 3.84(\mathrm{~s}, 3 \mathrm{H}) \mathrm{ppm}$. The ${ }^{1} \mathrm{H}$ NMR spectrum is consistent with that reported in the literature. $^{4}$
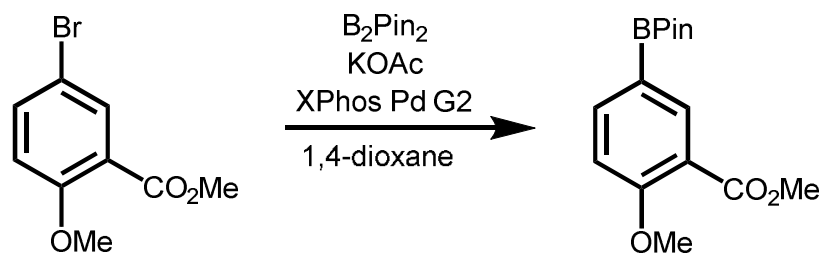

A $250 \mathrm{~mL}$ 3-neck roundbottom flask equipped with a stir bar and reflux condenser was charged with methyl 5-bromo-2-methoxybenzoate (10.0 g, $40.8 \mathrm{mmol}, 1.00$ eq.), bis(pinacolato)diboron (11.4 g, $44.8 \mathrm{mmol}, 1.10$ eq.), potassium acetate ( $12.0 \mathrm{~g}, 122 \mathrm{mmol}, 3.00$ eq.), and XPhos Pd G2 precatalyst $(645 \mathrm{mg}, 0.82 \mathrm{mmol}, 0.02$ eq.). The flask was placed under high vacuum for 5 minutes and then back-filled with nitrogen. This process was repeated a total of three times. 
Next, degassed 1,4-dioxane $(80 \mathrm{~mL})$ was added via syringe, and the reaction mixture was allowed to stir at reflux for $14 \mathrm{~h}$. The reaction mixture was allowed to cool to room temperature, and the 1,4-dioxane was removed in vacuo. The crude product was partitioned between $\mathrm{CH}_{2} \mathrm{Cl}_{2}$ $(150 \mathrm{~mL})$ and water $(150 \mathrm{~mL})$. The phases were separated, and the aqueous layer was further extracted with $\mathrm{CH}_{2} \mathrm{Cl}_{2}(2 \times 50 \mathrm{~mL})$. The combined organic extracts were dried over $\mathrm{MgSO}_{4}$, filtered through celite, eluting with $\mathrm{CH}_{2} \mathrm{Cl}_{2}(300 \mathrm{~mL})$, and concentrated in vacuo. The resulting light brown solid was triturated with cold hexanes $(50 \mathrm{~mL})$, filtered, and washed with additional cold hexanes $(2 \times 25 \mathrm{~mL})$ to yield methyl 2-methoxy-5-(4,4,5,5-tetramethyl-1,3,2-dioxaborolan2-yl)benzoate ( $9.86 \mathrm{~g}, 83 \%$ yield) as a fluffy white solid. ${ }^{1} \mathrm{H}$ NMR $\left(300 \mathrm{MHz}, \mathrm{CDCl}_{3}\right): \delta 8.22(\mathrm{~s}$, $1 \mathrm{H}), 7.90(\mathrm{~d}, \mathrm{~J}=8 \mathrm{~Hz}, 1 \mathrm{H}), 6.95(\mathrm{~d}, \mathrm{~J}=8 \mathrm{~Hz}, 1 \mathrm{H}), 3.92(\mathrm{~s}, 3 \mathrm{H}), 3.87(\mathrm{~s}, 3 \mathrm{H}), 1.33(\mathrm{~s}, 12 \mathrm{H}) \mathrm{ppm}$. The ${ }^{1} \mathrm{H}$ NMR spectrum is consistent with that reported in the literature. ${ }^{5}$

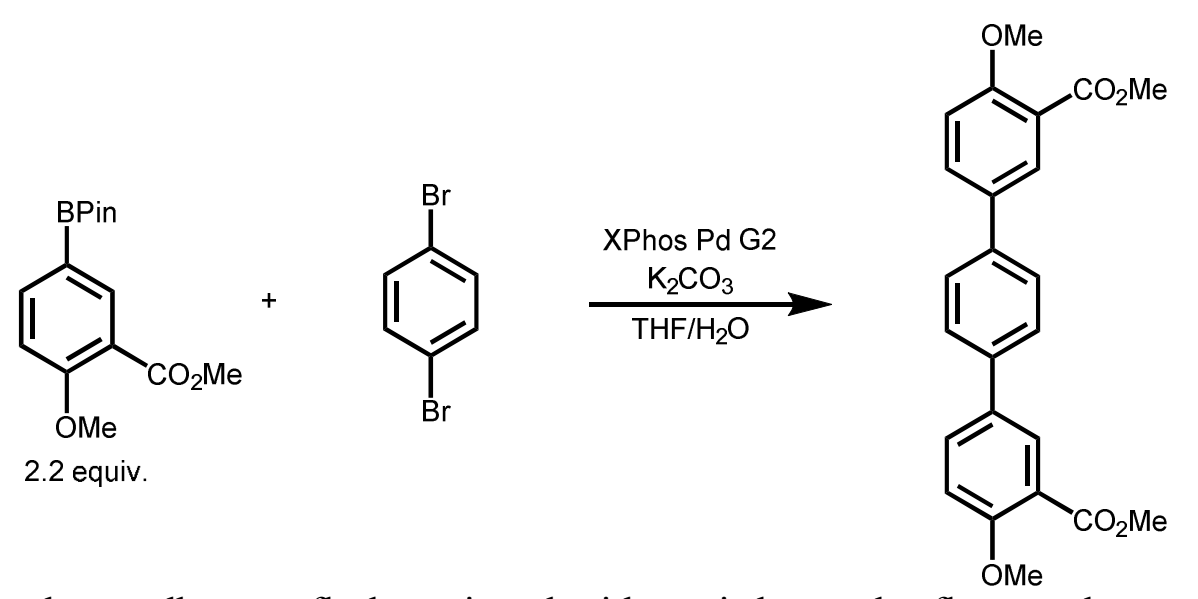

A $50 \mathrm{~mL} 3$-neck roundbottom flask equipped with a stir bar and reflux condenser was charged with methyl 2-methoxy-5-(4,4,5,5-tetramethyl-1,3,2-dioxaborolan-2-yl)benzoate (1.29 g, 4.40 mmol, 2.20 eq.), 1,4-dibromobenzene (472 mg, $2.00 \mathrm{mmol}, 1.00$ eq.), and XPhos Pd G2 (79 mg, $0.10 \mathrm{mmol}, 0.05$ eq.). The flask was placed under high vacuum for 5 minutes and then backfilled with nitrogen. This process was repeated a total of three times. Next, degassed THF $(8 \mathrm{~mL})$ and degassed aqueous $\mathrm{K}_{2} \mathrm{CO}_{3}(0.5 \mathrm{M}, 16 \mathrm{~mL}, 8 \mathrm{mmol}$, 4 eq. $)$ were added via syringe, and the reaction mixture was allowed to stir at reflux for $14 \mathrm{~h}$, during which time a gray solid precipitated from solution. The reaction mixture was allowed to cool to room temperature, and the reaction mixture was poured into cold water $(75 \mathrm{~mL})$. The non-homogenous solution was filtered, and the precipitate was washed thoroughly with cold water $(3 \times 10 \mathrm{~mL})$. The resulting gray solid was dissolved in hot $\mathrm{CH}_{2} \mathrm{Cl}_{2}(100 \mathrm{~mL})$. The solution was filtered through celite, eluting with $\mathrm{CH}_{2} \mathrm{Cl}_{2}(300 \mathrm{~mL})$, and concentrated in vacuo to yield a brown solid. This solid was triturated with cold methanol $(20 \mathrm{~mL})$, filtered, and washed with cold methanol $(2 \times 5 \mathrm{~mL})$, to yield dimethyl 4,4"-dimethoxy-[1,1':4',1"-terphenyl]-3,3"-dicarboxylate (769 mg, 95\% yield) as an off-white solid. ${ }^{1} \mathrm{H}$ NMR $\left(300 \mathrm{MHz}, \mathrm{CDCl}_{3}\right): \delta 8.09(\mathrm{~d}, \mathrm{~J}=2 \mathrm{~Hz}, 2 \mathrm{H}), 7.74(\mathrm{dd}, \mathrm{J}=9,2 \mathrm{~Hz}$, 2H), 7.63 (s, 4H), 7.07 (d, J = 9 Hz, 2H), 3.96 (s, 6H), 3.93 (s, 6H) ppm. 

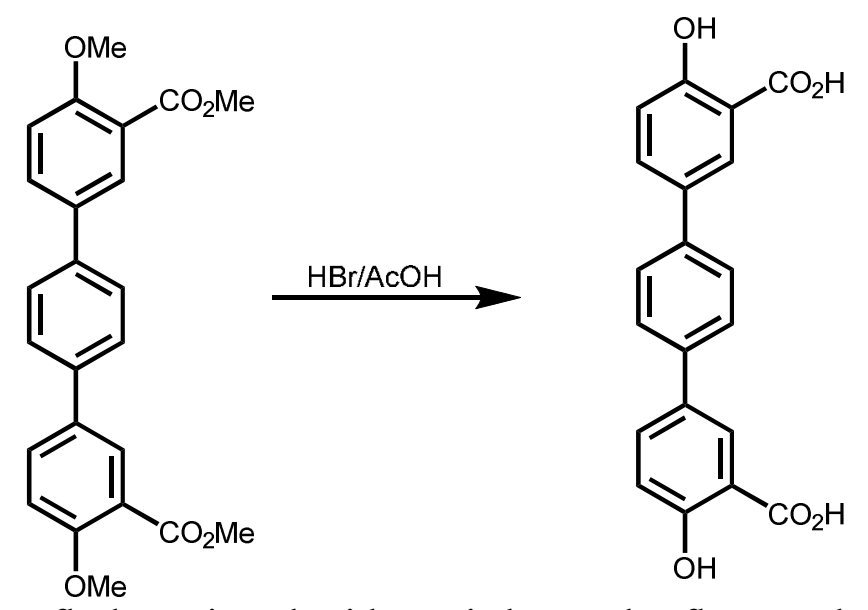

A $100 \mathrm{~mL}$ roundbottom flask equipped with a stir bar and reflux condenser was charged with dimethyl 4,4"-dimethoxy-[1,1':4',1"-terphenyl]-3,3"-dicarboxylate (760 mg, $1.87 \mathrm{mmol}, 1.00$ eq.). $\mathrm{HBr}(75 \mathrm{~mL})$ and $\mathrm{AcOH}(75 \mathrm{~mL})$ were added, and the nonhomogenous reaction mixture was allowed to stir at reflux for $48 \mathrm{~h}$. During this time, the starting material dissolved, the reaction mixture turned orange, and a white solid precipitated from solution. The reaction mixture was allowed to cool to room temperature, poured into cold water $(200 \mathrm{~mL})$, and filtered. The precipitate was washed with cold water $(2 \times 50 \mathrm{~mL})$ to yield $\mathbf{H}_{4}$ (dotpde) (4,4"-dihydroxy[1,1':4',1"-terphenyl]-3,3"-dicarboxylic acid) (608 mg, 93\%) as an off-white solid. ${ }^{1} \mathrm{H}$ NMR (400 MHz, DMSO-d $\left.\mathrm{d}_{6}\right): \delta 14.0$ (bs, 2H), 11.3 (bs, 2H), 8.08 (s, 2H), $7.88(\mathrm{~d}, \mathrm{~J}=9 \mathrm{~Hz}, 2 \mathrm{H}), 7.70(\mathrm{~s}$, 4H), $7.08(\mathrm{~d}, \mathrm{~J}=9 \mathrm{~Hz}, 2 \mathrm{H}) \mathrm{ppm} ;{ }^{13} \mathrm{C}$ NMR $(100 \mathrm{MHz}$, DMSO-d 6 ): $\delta$ 172.2, 161.1, 138.1, 134.2, 131.1, 128.2, 127.1, 118.3, 113.8 ppm. Anal. Calc. for $\mathrm{C}_{20} \mathrm{H}_{14} \mathrm{O}_{6}$ : C, 68.57; H, 4.03. Found: $\mathrm{C}$, $68.28 ; \mathrm{H}, 4.26$.

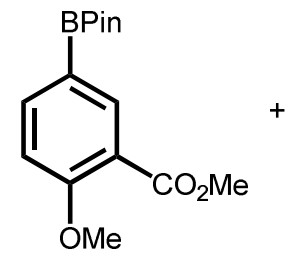

2.2 equiv.<smiles>Fc1c(F)c(F)c(Br)c(Br)c1F</smiles>

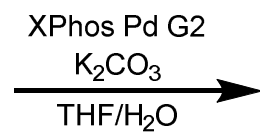

A $50 \mathrm{~mL}$ 3-neck roundbottom flask equipped with a stir bar and reflux condenser was charged with methyl 2-methoxy-5-(4,4,5,5-tetramethyl-1,3,2-dioxaborolan-2-yl)benzoate (1.29 g, 4.40 mmol, 2.20 eq.), 1,4-dibromo-2,3,5,6-tetrafluorobenzene (616 mg, $2.00 \mathrm{mmol}, 1.00$ eq.), and XPhos Pd G2 (79 mg, $0.10 \mathrm{mmol}, 0.05$ eq.). The flask was placed under high vacuum for 5 minutes and then back-filled with nitrogen. This process was repeated a total of three times. Next, degassed THF $(8 \mathrm{~mL})$ and degassed aqueous $\mathrm{K}_{2} \mathrm{CO}_{3}(0.5 \mathrm{M}, 16 \mathrm{~mL}, 8 \mathrm{mmol}, 4$ eq.) were added via syringe, and the reaction mixture was allowed to stir at reflux for $14 \mathrm{~h}$, during which time a gray solid precipitated from solution. The reaction mixture was allowed to cool to room 
temperature, and the reaction mixture was poured into cold water $(75 \mathrm{~mL})$. The non-homogenous solution was filtered, and the precipitate was washed thoroughly with cold water $(3 \times 10 \mathrm{~mL})$. The resulting gray solid was dissolved in hot $\mathrm{CH}_{2} \mathrm{Cl}_{2}(100 \mathrm{~mL})$. The solution was filtered through celite, eluting with $\mathrm{CH}_{2} \mathrm{Cl}_{2}(300 \mathrm{~mL})$, and concentrated in vacuo to yield a yellow solid. This solid was triturated with cold methanol $(20 \mathrm{~mL})$, filtered, and washed with cold methanol (2 x $5 \mathrm{~mL}$ ), to yield dimethyl 2',3',5',6'-tetrafluoro-4,4"-dimethoxy-[1,1':4',1"-terphenyl]-3,3"dicarboxylate (613 mg, $64 \%$ yield) as an off-white solid. ${ }^{1} \mathrm{H}$ NMR $\left(300 \mathrm{MHz}, \mathrm{CDCl}_{3}\right): \delta 7.86(\mathrm{~d}$, $\mathrm{J}=2 \mathrm{~Hz}, 2 \mathrm{H}), 7.82(\mathrm{dd}, \mathrm{J}=9,2 \mathrm{~Hz}, 2 \mathrm{H}), 7.24(\mathrm{~d}, \mathrm{~J}=9 \mathrm{~Hz}, 2 \mathrm{H}), 3.59(\mathrm{~s}, 6 \mathrm{H}), 3.81(\mathrm{~s}, 6 \mathrm{H}) \mathrm{ppm}$; ${ }^{19} \mathrm{~F} \mathrm{NMR}\left(376 \mathrm{MHz}, \mathrm{CDCl}_{3}\right): \delta-143.9 \mathrm{ppm}$.
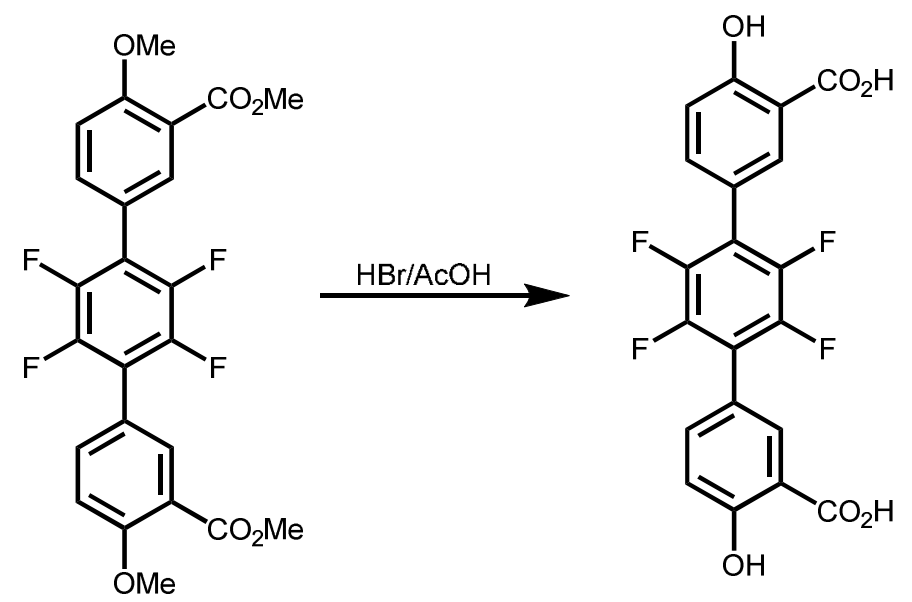

A $100 \mathrm{~mL}$ roundbottom flask equipped with a stir bar and reflux condenser was charged with dimethyl 2',3',5',6'-tetrafluoro-4,4"-dimethoxy-[1,1':4',1"-terphenyl]-3,3"-dicarboxylate (478 mg, $1.00 \mathrm{mmol}, 1.00$ eq.). $\mathrm{HBr}(50 \mathrm{~mL})$ and $\mathrm{AcOH}(50 \mathrm{~mL})$ were added, and the nonhomogenous reaction mixture was allowed to stir at reflux for $48 \mathrm{~h}$. The reaction mixture was allowed to cool to room temperature, poured into cold water $(100 \mathrm{~mL})$, and filtered. The precipitate was washed with cold water $(2 \times 50 \mathrm{~mL})$ to yield $\mathbf{H}_{4}\left(\mathbf{d o t p d c}^{\mathbf{F}}\right)\left(2^{\prime}, 3^{\prime}, 5^{\prime}, 6\right.$ '-tetrafluoro-4,4"-dihydroxy[1,1':4',1"-terphenyl]-3,3"-dicarboxylic acid) $(287 \mathrm{mg}, 68 \%)$ as an off-white solid. ${ }^{1} \mathrm{H}$ NMR (400 MHz, DMSO-d $\left.)_{6}\right): \delta 7.98(\mathrm{~s}, 2 \mathrm{H}), 7.81(\mathrm{~d}, \mathrm{~J}=9 \mathrm{~Hz}, 2 \mathrm{H}), 7.16(\mathrm{~d}, \mathrm{~J}=9 \mathrm{~Hz}, 2 \mathrm{H}) \mathrm{ppm} ;{ }^{13} \mathrm{C}$ NMR (100 MHz, DMSO-d $\left.{ }_{6}\right): \delta 171.3,161.7,143.7(\mathrm{dm}, \mathrm{J}=241 \mathrm{~Hz}), 136.9,132.0,117.8,117.4,113.5$ ppm $\left(\mathrm{a}^{13} \mathrm{C}\right.$ resonance for the biphenyl carbon on the central ring could not readily be observed due to the poor solubility of this compound in DMSO- $\mathrm{d}_{6}$ and the weak signal strength of this resonance resulting from C-F coupling); ${ }^{19} \mathrm{~F}$ NMR (376 MHz, DMSO-d 6 ): $\delta-144.0 \mathrm{ppm}$. HRMS (ESI-TOF) m/z: [M - H] ${ }^{-}$Calcd for $\mathrm{C}_{20} \mathrm{H}_{9} \mathrm{O}_{6} \mathrm{~F}_{4} 421.03411$; Found 421.0330 . 

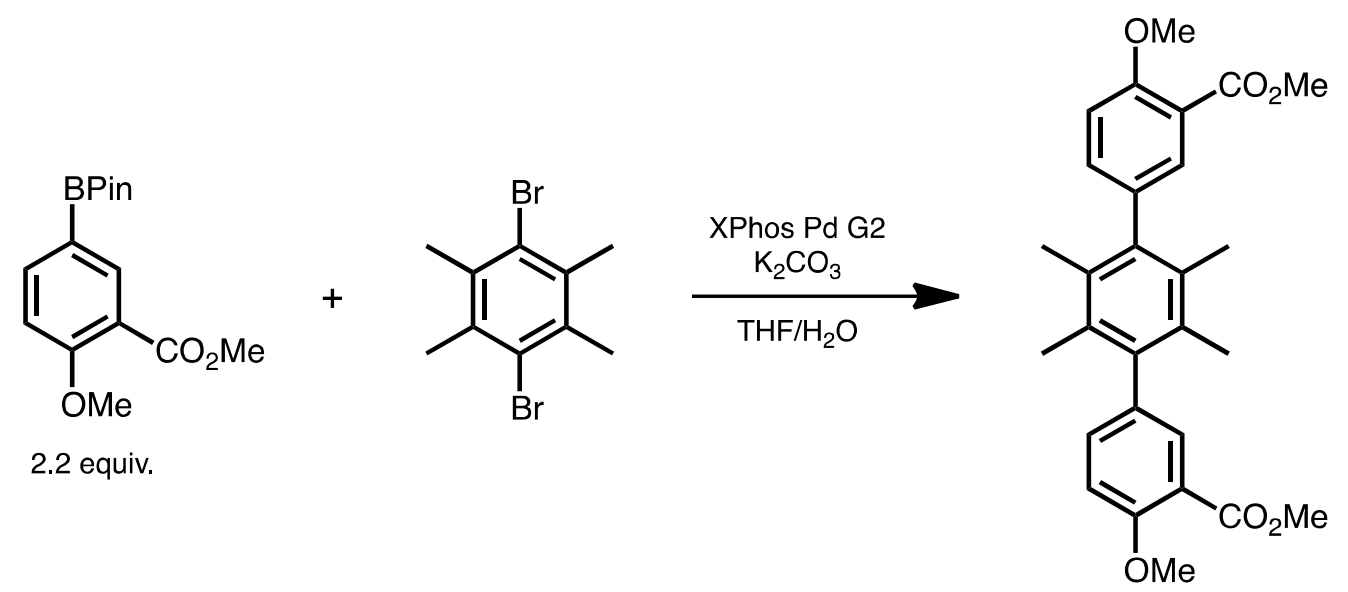

A $50 \mathrm{~mL} 3$-neck roundbottom flask equipped with a stir bar and reflux condenser was charged with methyl 2-methoxy-5-(4,4,5,5-tetramethyl-1,3,2-dioxaborolan-2-yl)benzoate (1.11 g, 3.77 mmol, 2.20 eq.), 1,4-dibromo-2,3,5,6-tetramethylbenzene (500 mg, $1.72 \mathrm{mmol}, 1.00$ eq.), and XPhos Pd G2 (68 mg, $0.09 \mathrm{mmol}, 0.05$ eq.). The flask was placed under high vacuum for 5 minutes and then back-filled with nitrogen. This process was repeated a total of three times. Next, degassed THF $(8 \mathrm{~mL})$ and degassed aqueous $\mathrm{K}_{2} \mathrm{CO}_{3}(0.5 \mathrm{M}, 14 \mathrm{~mL}, 7 \mathrm{mmol}, 4$ eq.) were added via syringe, and the reaction mixture was allowed to stir at reflux for $14 \mathrm{~h}$, during which time a gray solid precipitated from solution. The reaction mixture was allowed to cool to room temperature, and the reaction mixture was poured into cold water $(75 \mathrm{~mL})$. The non-homogenous solution was filtered, and the precipitate was washed thoroughly with cold water $(3 \times 10 \mathrm{~mL})$. The resulting gray solid was dissolved in hot $\mathrm{CH}_{2} \mathrm{Cl}_{2}(100 \mathrm{~mL})$. The solution was filtered through celite, eluting with $\mathrm{CH}_{2} \mathrm{Cl}_{2}(300 \mathrm{~mL})$, and concentrated in vacuo to yield a brown solid. This solid was triturated with cold methanol $(20 \mathrm{~mL})$, filtered, and washed with cold methanol (2 x $5 \mathrm{~mL}$ ), to yield dimethyl 4,4"-dimethoxy-2',3',5',6'-tetramethyl-[1,1':4',1"-terphenyl]-3,3"dicarboxylate $\left(610 \mathrm{mg}, 76 \%\right.$ yield) as an off-white solid. ${ }^{1} \mathrm{H}$ NMR $\left(300 \mathrm{MHz}, \mathrm{CDCl}_{3}\right): \delta 7.62$ (dd, 2H), $7.26\left(\mathrm{~m}, 2 \mathrm{H}\right.$, under $\mathrm{CDCl}_{3}$ peak), $7.07(\mathrm{~d}, \mathrm{~J}=9 \mathrm{~Hz}, 2 \mathrm{H}), 3.98(\mathrm{~s}, 6 \mathrm{H}), 3.88(\mathrm{~s}, 6 \mathrm{H}) \mathrm{ppm}$.

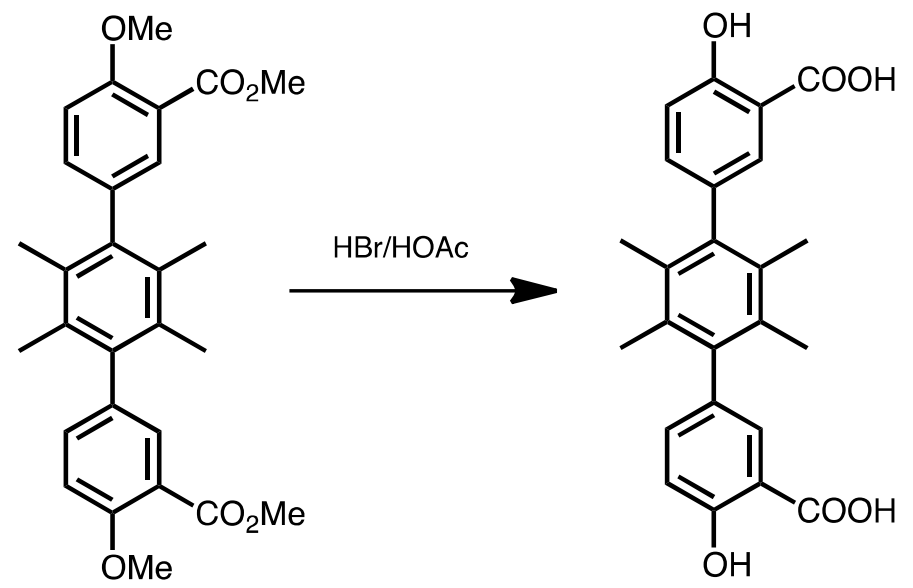

A $100 \mathrm{~mL}$ roundbottom flask equipped with a stir bar and reflux condenser was charged with 4,4"-dimethoxy-2',3',5',6'-tetramethyl-[1,1':4',1"-terphenyl]-3,3"-dicarboxylate (420 $\mathrm{mg}, \quad 0.91$ mmol, 1.00 eq.). $\mathrm{HBr}(40 \mathrm{~mL})$ and $\mathrm{AcOH}(40 \mathrm{~mL})$ were added, and the nonhomogenous reaction mixture was allowed to stir at reflux for $48 \mathrm{~h}$. During this time, the starting material dissolved, 
the reaction mixture turned orange, and a white solid precipitated from solution. The reaction mixture was allowed to cool to room temperature, poured into cold water $(200 \mathrm{~mL})$, and filtered. The precipitate was washed with cold water $(2 \times 50 \mathrm{~mL})$ to yield $\mathbf{H}_{4}\left(\right.$ dotpdc $\left.^{\mathrm{CH} 3}\right)(4,4$ "dihydroxy-2',3',5',6'-tetramethyl-[1,1':4',1"-terphenyl]-3,3"-dicarboxylic acid) (309 mg, 84\%) as an off-white solid. ${ }^{1} \mathrm{H}$ NMR (400 MHz, DMSO-d 6 ): $\delta 7.48(\mathrm{~d}, \mathrm{~J}=2 \mathrm{~Hz}, 2 \mathrm{H}), 7.27(\mathrm{~d}, \mathrm{~J}=9 \mathrm{~Hz}$, 2H), 7.05 (dd, J = 9, $2 \mathrm{~Hz}, 2 \mathrm{H}), 1.89$ (s, 12H) ppm; ${ }^{13} \mathrm{C}$ NMR (100 MHz, DMSO-d 6 ): $\delta 171.9$, 159.8, 139.6, 136.6, 132.7, 131.6, 130.4, 117.3, 113.0 18.0. Anal. Calc. for $\mathrm{C}_{24} \mathrm{H}_{22} \mathrm{O}_{6}: \mathrm{C}, 70.92$; H, 5.46. Found: C, 70.65; H, 5.70.

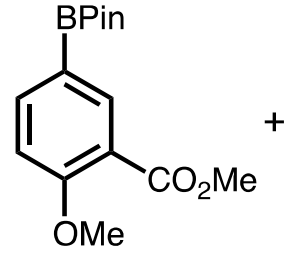

2.2 equiv.
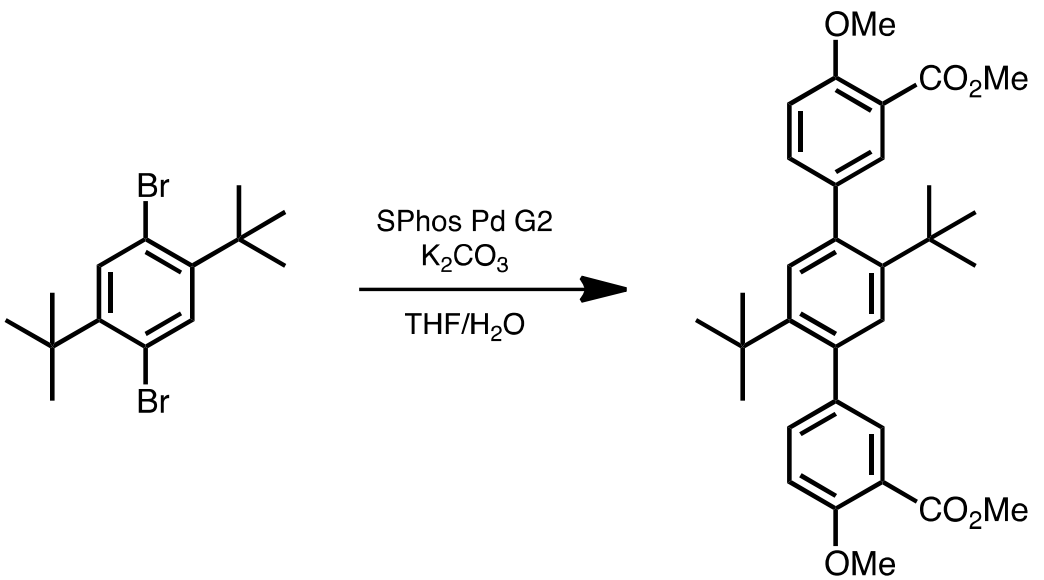

A $50 \mathrm{~mL}$ 3-neck roundbottom flask equipped with a stir bar and reflux condenser was charged with methyl 2-methoxy-5-(4,4,5,5-tetramethyl-1,3,2-dioxaborolan-2-yl)benzoate (0.466 g, 1.56 mmol, 2.20 eq.), 1,4-dibromo-2,5-ditert-butylbenzene (250 mg, $0.72 \mathrm{mmol}, 1.00$ eq.), and SPhos Pd G2 (26 mg, $0.04 \mathrm{mmol}, 0.05$ eq.). Note that the ligand SPhos was used rather than XPhos due to its slightly smaller size. The flask was placed under high vacuum for 5 minutes and then backfilled with nitrogen. This process was repeated a total of three times. Next, degassed THF (16 $\mathrm{mL})$ and degassed aqueous $\mathrm{K}_{2} \mathrm{CO}_{3}(0.5 \mathrm{M}, 6 \mathrm{~mL}, 3 \mathrm{mmol}, 4$ eq.) were added via syringe, and the reaction mixture was allowed to stir at room temperature for $24 \mathrm{~h}$, then $60{ }^{\circ} \mathrm{C}$ overnight. The reaction mixture was allowed to cool to room temperature, and the reaction mixture was poured into cold water $(75 \mathrm{~mL})$. The non-homogenous solution was filtered, and the precipitate was washed thoroughly with cold water $(3 \times 10 \mathrm{~mL})$, methanol $(3 \times 10 \mathrm{~mL})$, and hexanes $(3 \times 10$ $\mathrm{mL})$. The resulting gray solid was dissolved in $\mathrm{CH}_{2} \mathrm{Cl}_{2}(100 \mathrm{~mL})$. The solution was filtered through celite, eluting with $\mathrm{CH}_{2} \mathrm{Cl}_{2}(300 \mathrm{~mL})$, and concentrated in vacuo to yield dimethyl 2',5'di-tert-butyl-4,4"-dimethoxy-[1,1':4',1"-terphenyl]-3,3"-dicarboxylate (220 $\mathrm{mg}, 59 \%$ yield) as a white solid. ${ }^{1} \mathrm{H}$ NMR (300 MHz, $\left.\mathrm{CDCl}_{3}\right): \delta 7.78(\mathrm{~d}, \mathrm{~J}=2 \mathrm{~Hz}, 2 \mathrm{H}), 7.43(\mathrm{dd}, \mathrm{J}=9,2 \mathrm{~Hz}, 2 \mathrm{H})$, 7.08 (s, 2H), 7.00 (d, J = 9 Hz, 2H), 3.97 (s, 6H), 3.89 (s, 6H), 1.14 (s, 18H) ppm. 

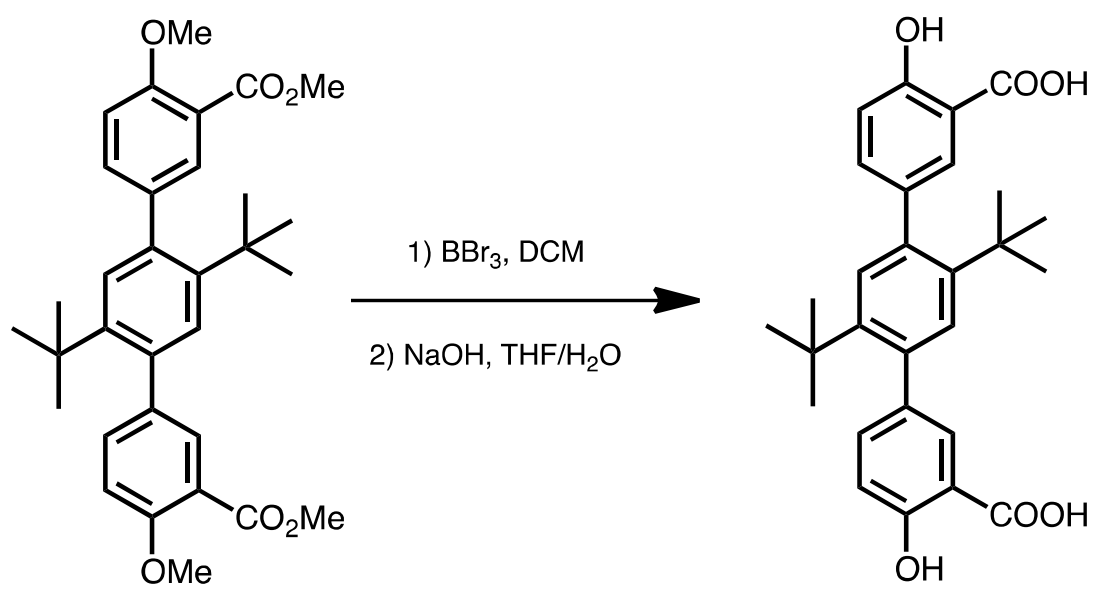

Because the tert-butyl groups are not stable under refluxing $\mathrm{HBr} / \mathrm{HOAc}$, alternative conditions were used to remove the methyl protecting groups. A $100 \mathrm{~mL}$ schlenk flask equipped with a stir bar was charged with 2',5'-di-tert-butyl-4,4"-dimethoxy-[1,1':4',1"-terphenyl]-3,3"-dicarboxylate (220 mg, $0.42 \mathrm{mmol}, 1.00$ eq.) and $50 \mathrm{~mL}$ of DCM. The solution was vigorously stirred and cooled to $-78{ }^{\circ} \mathrm{C}$, and $\mathrm{BBr}_{3}$ was added dropwise (1M solution in DCM, $5.1 \mathrm{~mL}, 5.1 \mathrm{mmol}, 12$ eq.) under an argon atmosphere. The reaction was stirred at room temperature for $24 \mathrm{~h}$. The excess $\mathrm{BBr}_{3}$ was quenched with water, and the resulting white precipitate was washed with $\mathrm{H}_{2} \mathrm{O}$ $(3 \times 50 \mathrm{~mL})$. A small amount of methyl ester $(\sim 30 \%)$ still present in the material was subsequently hydrolyzed by stirring the material in $10 \mathrm{~mL}$ of THF and $10 \mathrm{ML}$ of $1 \mathrm{M} \mathrm{NaOH}$ at 50 ${ }^{\circ} \mathrm{C}$ overnight. The solution was neutralized using $\mathrm{HCl}$, the THF removed in vacuo, and the white precipitate washed with $\mathrm{H}_{2} \mathrm{O}(3 \times 50 \mathrm{~mL})$ to afford $\mathbf{H}_{\mathbf{4}}\left(\mathbf{d o t p d c}^{\mathbf{t} \mathbf{B u}}\right)\left(2^{\prime}, 5^{\prime}\right.$-di-tert-butyl-4,4"dihydroxy-[1,1':4',1"-terphenyl]-3,3"-dicarboxylic acid) (150 mg over two steps, 76\%). ${ }^{1} \mathrm{H}$ NMR (400 MHz, DMSO-d $\left.)_{6}\right): \delta 7.64(\mathrm{~d}, \mathrm{~J}=2 \mathrm{~Hz}, 2 \mathrm{H}), 7.43$ (dd, J = 9, $\left.2 \mathrm{~Hz}, 2 \mathrm{H}\right), 7.02$ (s. 2H), 6.99 (d, $\mathrm{J}=8 \mathrm{~Hz}, 2 \mathrm{H}), 1.10(\mathrm{~s}, 18 \mathrm{H}) \mathrm{ppm} ;{ }^{13} \mathrm{C}$ NMR $(100 \mathrm{MHz}$, DMSO-d 6 ): $\delta 171.8,159.9,144.1,139.2$, 136.9, 135.3, 130.7, 126.4, 118.0, 116.2, 35.4, 32.3. Anal. Calc. for $\mathrm{C}_{28} \mathrm{H}_{30} \mathrm{O}_{6}: \mathrm{C}, 72.71 ; \mathrm{H}, 6.54$. Found: C, 72.39; H, 6.76. 


\section{Powder X-ray diffraction data collection and analysis.}

Sample preparation and data collection: For all powder X-ray diffraction measurements, $1.0 \mathrm{~mm}$ diameter borosilicate capillaries were packed with sample (to roughly $8-10 \mathrm{~mm}$ in height) inside an $\mathrm{N}_{2}$-filled glovebox. For high-resolution powder X-ray diffraction data, samples were then attached to custom designed gas cells, brought out of the glovebox, evacuated, and flame-sealed. Acetonitrile-solvated $\mathrm{Fe}_{2}($ dotpdc $) \cdot 2 \mathrm{MeCN}, \mathrm{Fe}_{2}\left(\operatorname{dotpdc}^{\mathrm{F}}\right) \cdot 2 \mathrm{MeCN}, \mathrm{Fe}_{2}\left(\operatorname{dotpdc}^{\mathrm{CH} 3}\right) \cdot 2 \mathrm{MeCN}$, and $\mathrm{Fe}_{2}\left(\operatorname{dotpdc}^{t \mathrm{Bu}}\right) \cdot 2 \mathrm{MeCN}$ were collected on Beamline 17-BM-B $(\lambda=$ wavelength of $0.72768 \AA)$ at the Advanced Photon Source at Argonne National Laboratory. High-resolution powder X-ray diffraction patterns of activated (desolvated) $\mathrm{Fe}_{2}$ (dotpdc) and $\mathrm{Fe}_{2}\left(\operatorname{dotpdc}^{\mathrm{F}}\right.$ ) were collected at Beamline 17-BM-B. For characterization of frameworks post-catalysis, the capillaries were temporarily sealed under $\mathrm{N}_{2}$ with silicone grease and then flame-sealed. The resulting powder Xray diffraction patterns were collected using a Bruker AXS D8 Advance diffractometer equipped with $\mathrm{CuK} \alpha$ radiation $(\lambda=1.5418 \AA)$.

General data analysis: The powder data analysis (pattern indexing, profile fitting, Pawley refinement, and crystal structure model) was performed with the program TOPAS-Academic V4.125. Specifically, a standard peak search, followed by indexing via the Single Value Decomposition approach allowed the determination of approximate unit cell dimensions. Precise unit cell dimensions were determined by performing a structureless Pawley refinement in TOPAS-Academic (see Figures S1-S4). Structural models (assuming frameworks adopt the same structural connectivity as the $\mathrm{M}_{2}$ (dobdc) series) were constructed in Materials Studio (Materials Studio v. 8, Accelrys Software Inc.) and optimized using the Forcite module, which were then used to perform Rietveld refinements of powder X-ray diffraction patterns of activated $\mathrm{Fe}_{2}\left(\right.$ dotpdc) and $\mathrm{Fe}_{2}\left(\right.$ dotpdc $\left.^{\mathrm{F}}\right)$ in TOPAS-Academic.

Structure solution and Rietveld refinement of activated $\mathrm{Fe}_{2}\left(\right.$ dotpdc) and $\mathrm{Fe}_{2}\left(\right.$ dotpdc $\left.{ }^{F}\right)$ : A structural model of $\mathrm{Fe}_{2}$ (dotpdc) was constructed in Materials Studio based on expansion from the reported $\mathrm{Fe}_{2}(\mathrm{dobdc})$ crystal structure, which was then used to perform a Rietveld refinement of the experimental $\mathrm{Fe}_{2}$ (dotpdc) powder pattern in TOPAS-Academic V4.1. In this refinement, the instrumental and sample parameters were freely refined. A single refined isotropic thermal parameter was assigned to the $\mathrm{Fe}$ atom. A single refined isotropic thermal parameter was assigned to the majority of atoms of the dotpdc ${ }^{4-}$ ligand, with the exception of the atoms of the central phenyl ring, which had a separately refined isotropic thermal parameter. The atomic positions could not be refined, as the X-ray diffraction pattern did not have enough detail to allow for accurate determination of light atoms. While the powder X-ray diffraction pattern was not of high enough quality to allow for ab initio solution of the structure of $\mathrm{Fe}_{2}$ (dotpdc), the resulting calculated diffraction pattern for the constructed structural model is in agreement with the experimental diffraction pattern (Figure S5). This agreement lends us to believe that the structural model is in fact a fair approximation of the structure of $\mathrm{Fe}_{2}$ (dotpdc). The structure solution and Rietveld refinement of $\mathrm{Fe}_{2}\left(\operatorname{dotpdc}^{\mathrm{F}}\right)$ was performed in a similar manner (Figure S5). 


\section{Mössbauer data collection and analysis.}

Iron-57 Mössbauer spectra were obtained at $100 \mathrm{~K}$ with a constant acceleration spectrometer and a cobalt-57 rhodium source. Prior to measurements the spectrometer was calibrated at $295 \mathrm{~K}$ with $\alpha$-iron foil. Samples were prepared inside an $\mathrm{N}_{2}$-filled glove box and contained $20 \mathrm{mg} / \mathrm{cm}^{2}$ of sample $\left(\sim 3\right.$ to $4 \mathrm{mg} / \mathrm{cm}^{2}$ of iron) diluted with boron nitride. All spectra were fit with Lorentzian quadrupole doublets using the WMOSS Mössbauer Spectral Analysis Software (www.wmoss.org). ${ }^{6}$ 


\section{Kinetic isotope effect determination.}

The kinetic isotope effect was determined via competition experiments between $\mathrm{C}_{6} \mathrm{H}_{12}$ and $\mathrm{C}_{6} \mathrm{D}_{12}$. For each framework, three separate reactions were run using different initial ratios of $\mathrm{C}_{6} \mathrm{H}_{12}$ and $\mathrm{C}_{6} \mathrm{D}_{12}\left(1: 1,1: 2\right.$, or 1:5 molar ratios of $\left.\mathrm{C}_{6} \mathrm{H}_{12}: \mathrm{C}_{6} \mathrm{D}_{12}\right)$. The general catalytic conditions were used, and after the reaction the ratio of cyclohexanol to $\left[\mathrm{D}_{11}\right]$-cyclohexanol was determined by GC-MS. A small amount of protio cyclohexanone was also produced (no [D $\left.\mathrm{D}_{10}\right]$ cyclohexanone was observed), and quantified using GC-MS and ${ }^{1} \mathrm{H}$ NMR. The ratio of protio to deuterated products $\left(\left[P_{\mathrm{H}}\right] /\left[P_{\mathrm{D}}\right]\right)$ was plotted against the initial $\mathrm{C}_{6} \mathrm{H}_{12} / \mathrm{C}_{6} \mathrm{D}_{12}$ ratio, and the kinetic isotope effect was taken as the slope of the best-fit line (see Figure S9 and Table S4). 


\section{Supplementary tables.}

Table S1. Unit cell parameters of acetonitrile-solvated $\mathrm{Fe}_{2}($ dotpdc) $2 \mathrm{MeCN}$, $\mathrm{Fe}_{2}\left(\operatorname{dotpdc}^{\mathrm{F}}\right) \cdot 2 \mathrm{MeCN}, \mathrm{Fe}_{2}\left(\operatorname{dotpdc}^{\mathrm{CH} 3}\right) \cdot 2 \mathrm{MeCN}$, and $\mathrm{Fe}_{2}\left(\operatorname{dotpdc}^{t \mathrm{Bu}}\right) \cdot 2 \mathrm{MeCN}$, determined via Pawley fitting of powder X-ray diffraction data.

\begin{tabular}{|c|c|c|c|c|}
\hline & $\begin{array}{c}\mathrm{Fe}_{2}(\text { dotpdc) } \\
\cdot 2 \mathrm{MeCN} \\
\end{array}$ & $\begin{array}{c}\mathrm{Fe}_{2}\left(\operatorname{dotpde}^{\mathrm{F}}\right) \\
\cdot 2 \mathrm{MeCN} \\
\end{array}$ & $\begin{array}{c}\mathrm{Fe}_{2}\left(\text { dotpde }^{\mathrm{CH} 3}\right) \\
\cdot 2 \mathrm{MeCN}\end{array}$ & $\begin{array}{c}\mathrm{Fe}_{2}\left(\operatorname{dotpdc}^{t \mathrm{Bu}}\right) \\
\cdot 2 \mathrm{MeCN}\end{array}$ \\
\hline Space group & $R \overline{3}$ & $R \overline{3}$ & $R \overline{3}$ & $R \overline{3}$ \\
\hline$a / \AA$ & $49.685(8)$ & $49.693(3)$ & $49.53(1)$ & $49.358(9)$ \\
\hline$c / \AA$ & $6.925(5)$ & $6.887(1)$ & $7.085(6)$ & $7.166(6)$ \\
\hline$V / \AA^{3}$ & $14806(11)$ & $14727(3)$ & $15050(15)$ & $15118(14)$ \\
\hline $\boldsymbol{R}_{\text {exp }}$ & 1.119 & 1.168 & 1.024 & 0.922 \\
\hline$R_{\mathrm{wp}}$ & 2.535 & 1.628 & 2.987 & 2.647 \\
\hline $\boldsymbol{R}_{\mathrm{p}}$ & 1.328 & 1.091 & 2.013 & 1.763 \\
\hline Wavelength (Å) & 0.727680 & 0.727680 & 0.727680 & 0.727680 \\
\hline Temperature & $298 \mathrm{~K}$ & $298 \mathrm{~K}$ & $298 \mathrm{~K}$ & $298 \mathrm{~K}$ \\
\hline
\end{tabular}


Table S2. Unit cell parameters of desolvated $\mathrm{Fe}_{2}\left(\right.$ dotpdc) and $\mathrm{Fe}_{2}\left(\operatorname{dotpdc}^{\mathrm{F}}\right)$ (activated under vacuum at $180^{\circ} \mathrm{C}$ ), determined via Pawley fitting of powder X-ray diffraction data.

\begin{tabular}{ccc}
\hline & $\mathbf{F e}_{2}(\mathbf{d o t p d c})$ & $\mathbf{F e}_{2}$ (dotpdc $\left.^{\mathrm{F}}\right)$ \\
\hline Space group & $R \overline{3}$ & $R \overline{3}$ \\
$\boldsymbol{a} / \AA$ & $49.86(2)$ & $49.88(4)$ \\
$\boldsymbol{c} / \AA$ & $6.84(1)$ & $6.84(2)$ \\
$\boldsymbol{V} / \AA^{\mathbf{3}}$ & $14730(30)$ & $14730(50)$ \\
$\boldsymbol{R}_{\text {exp }}$ & 0.471 & 0.323 \\
$\boldsymbol{R}_{\text {wp }}$ & 1.343 & 2.992 \\
$\boldsymbol{R}_{\mathbf{p}}$ & 0.939 & 1.841 \\
Wavelength $(\AA)$ & 0.727680 & 0.727680 \\
Temperature & $298 \mathrm{~K}$ & $298 \mathrm{~K}$ \\
\hline
\end{tabular}


Table S3. Mössbauer parameters for acetonitrile-solvated frameworks $\mathrm{Fe}_{2}(\mathrm{dotpdc}) \cdot 2 \mathrm{CD}_{3} \mathrm{CN}$, $\mathrm{Fe}_{2}\left(\operatorname{dotpdc}^{\mathrm{F}}\right) \cdot 2 \mathrm{CD}_{3} \mathrm{CN}, \mathrm{Fe}_{2}\left(\operatorname{dotpdc}^{\mathrm{CH} 3}\right) \cdot 2 \mathrm{CD}_{3} \mathrm{CN}$, and $\mathrm{Fe}_{2}\left(\operatorname{dotpdc}^{t \mathrm{Bu}}\right) \cdot 2 \mathrm{CD}_{3} \mathrm{CN}$, collected at 100 $\mathrm{K}$.

\begin{tabular}{|c|c|c|c|c|}
\hline & $\mathrm{Fe}_{2}$ (dotpdc) & $\mathrm{Fe}_{2}\left(\operatorname{dotpde}^{\mathrm{F}}\right)$ & $\mathrm{Fe}_{2}\left(\operatorname{dotpde}^{\mathrm{CH} 3}\right)$ & $\mathrm{Fe}_{2}\left(\operatorname{dotpde}^{t \mathrm{Bu}}\right)$ \\
\hline$\delta(\mathbf{m m} / \mathbf{s})$ & $1.267(3)$ & 1.271(3) & $1.264(2)$ & $1.259(2)$ \\
\hline$\left|\Delta E_{\mathrm{Q}}\right|(\mathrm{mm} / \mathrm{s})$ & $2.505(5)$ & $2.468(5)$ & $2.413(6)$ & $2.546(4)$ \\
\hline$\Gamma(\mathbf{m m} / \mathbf{s})$ & $0.39(1)$ & $0.39(1)$ & $0.31(1)$ & $0.31(1)$ \\
\hline
\end{tabular}


Table S4. Results of $\mathrm{C}_{6} \mathrm{H}_{12}$ and $\mathrm{C}_{6} \mathrm{D}_{12}$ competition experiments. $\left[P_{\mathrm{H}}\right] /\left[P_{\mathrm{D}}\right]$ is the molar ratio of protio to deuterated products.

\begin{tabular}{|c|c|c|c|c|}
\hline \multirow{2}{*}[\mathrm{C}_{6}\mathrm{H}_{12}]{$/\left[\mathrm{C}_{6} \mathrm{D}_{12}\right]$} & \multicolumn{4}{|c|}{$\left[P_{\mathrm{H}}\right] /\left[P_{\mathrm{D}}\right]$} \\
\hline & $\mathrm{Fe}_{2}$ (dotpdc) & $\mathrm{Fe}_{2}\left(\operatorname{dotpdc}^{\mathrm{F}}\right)$ & $\mathrm{Fe}_{2}\left(\operatorname{dotpdc} \mathrm{c}^{\mathrm{CH} 3}\right)$ & $\mathrm{Fe}_{2}\left(\operatorname{dotpdc}^{t \mathrm{Bu}}\right)$ \\
\hline 0.2 & 3.6 & 2.7 & 2.3 & 2.3 \\
\hline 0.5 & 7.5 & 6.9 & 7.1 & 7.2 \\
\hline 1 & 15.6 & 14.3 & 15.9 & 15.3 \\
\hline
\end{tabular}


Table S5. Single-site Langmuir-Freundlich parameters for cyclohexane gas adsorption on DMFsolvated $\quad \mathrm{Fe}_{2}(\operatorname{dotpdc}) \cdot 2 \mathrm{DMF}, \quad \mathrm{Fe}_{2}\left(\operatorname{dotpdc}^{\mathrm{F}}\right) \cdot 2 \mathrm{DMF}, \quad \mathrm{Fe}_{2}\left(\operatorname{dotpdc}^{\mathrm{CH} 3}\right) \cdot 2 \mathrm{DMF}, \quad$ and $\mathrm{Fe}_{2}\left(\operatorname{dotpdc}^{t \mathrm{Bu}}\right) \cdot 2 \mathrm{DMF}$.

$$
n=\frac{n_{s a t, 1} b_{1} P^{v_{1}}}{1+b_{1} P^{v_{1}}}
$$

\begin{tabular}{|c|c|c|c|c|}
\hline Framework & $\begin{array}{c}\text { Temperature } \\
\left({ }^{\circ} \mathrm{C}\right) \\
\end{array}$ & $\begin{array}{c}n_{1} \\
(\mathrm{mmol} / \mathrm{g}) \\
\end{array}$ & $\begin{array}{c}b_{1} \\
\left(\mathrm{bar}^{-1}\right) \\
\end{array}$ & $v_{1}$ \\
\hline \multirow{3}{*}{$\mathrm{Fe}_{2}($ dotpde) } & 25 & 3.08 & $1.48 \times 10^{4}$ & 1.27 \\
\hline & 35 & 3.14 & $6.80 \times 10^{3}$ & 1.27 \\
\hline & 45 & 3.30 & $3.24 \times 10^{3}$ & 1.27 \\
\hline \multirow{3}{*}{$\mathrm{Fe}_{2}\left(\operatorname{dotpdc}^{\mathrm{F}}\right)$} & 25 & 2.90 & $6.91 \times 10^{5}$ & 1.63 \\
\hline & 35 & 2.98 & $2.17 \times 10^{5}$ & 1.62 \\
\hline & 45 & 3.02 & $8.20 \times 10^{4}$ & 1.62 \\
\hline \multirow{3}{*}{$\mathrm{Fe}_{2}\left(\operatorname{dotpde}^{\mathrm{CH} 3}\right)$} & 25 & 2.77 & $8.78 \times 10^{5}$ & 1.55 \\
\hline & 35 & 2.72 & $3.06 \times 10^{5}$ & 1.55 \\
\hline & 45 & 2.71 & $1.09 \times 10^{5}$ & 1.55 \\
\hline \multirow{3}{*}{$\mathrm{Fe}_{2}\left(\operatorname{dotpde}^{t \mathrm{Bu}}\right)$} & 25 & 2.13 & $1.36 \times 10^{7}$ & 1.60 \\
\hline & 35 & 2.11 & $4.44 \times 10^{6}$ & 1.60 \\
\hline & 45 & 2.04 & $1.40 \times 10^{6}$ & 1.59 \\
\hline
\end{tabular}




\section{Supplementary figures.}

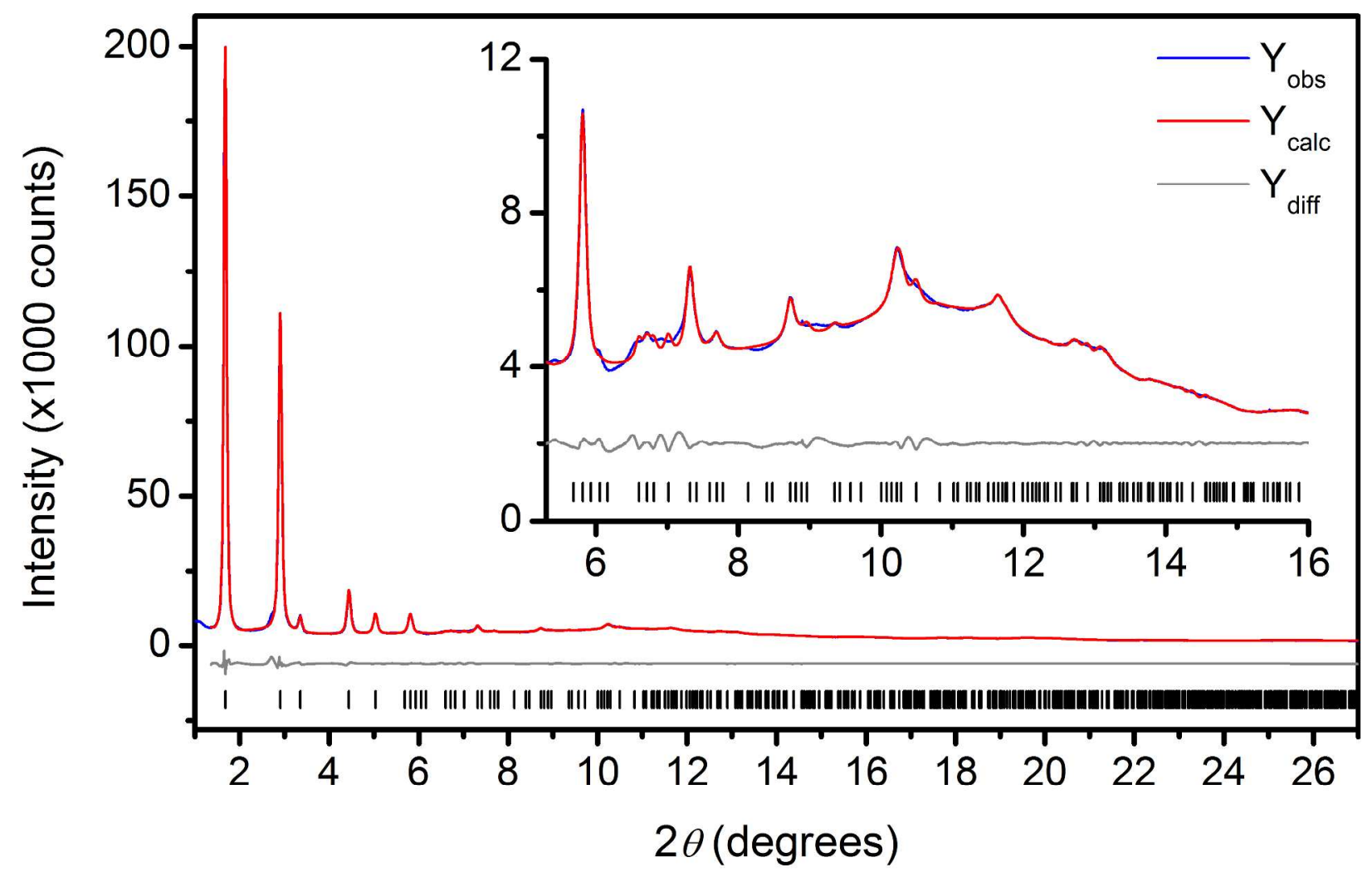

Figure S1. Pawley fit of acetonitrile-solvated $\mathrm{Fe}_{2}$ (dotpdc) $2 \mathrm{CD}_{3} \mathrm{CN}$ from $1.4^{\circ}$ to $27^{\circ}$. The powder $\mathrm{X}$-ray diffraction pattern of $\mathrm{Fe}_{2}$ (dotpdc) $\cdot 2 \mathrm{CD}_{3} \mathrm{CN}$ was taken at APS Beamline $17-\mathrm{BM}$ at $298 \mathrm{~K}$ with a wavelength of $0.727680 \AA$. Blue, red, and gray lines represent experimental data, calculated fits, and the difference between the two, respectively; black tick marks represent calculated Bragg peak positions. The inset shows a portion of the high angle region at a magnified scale. 


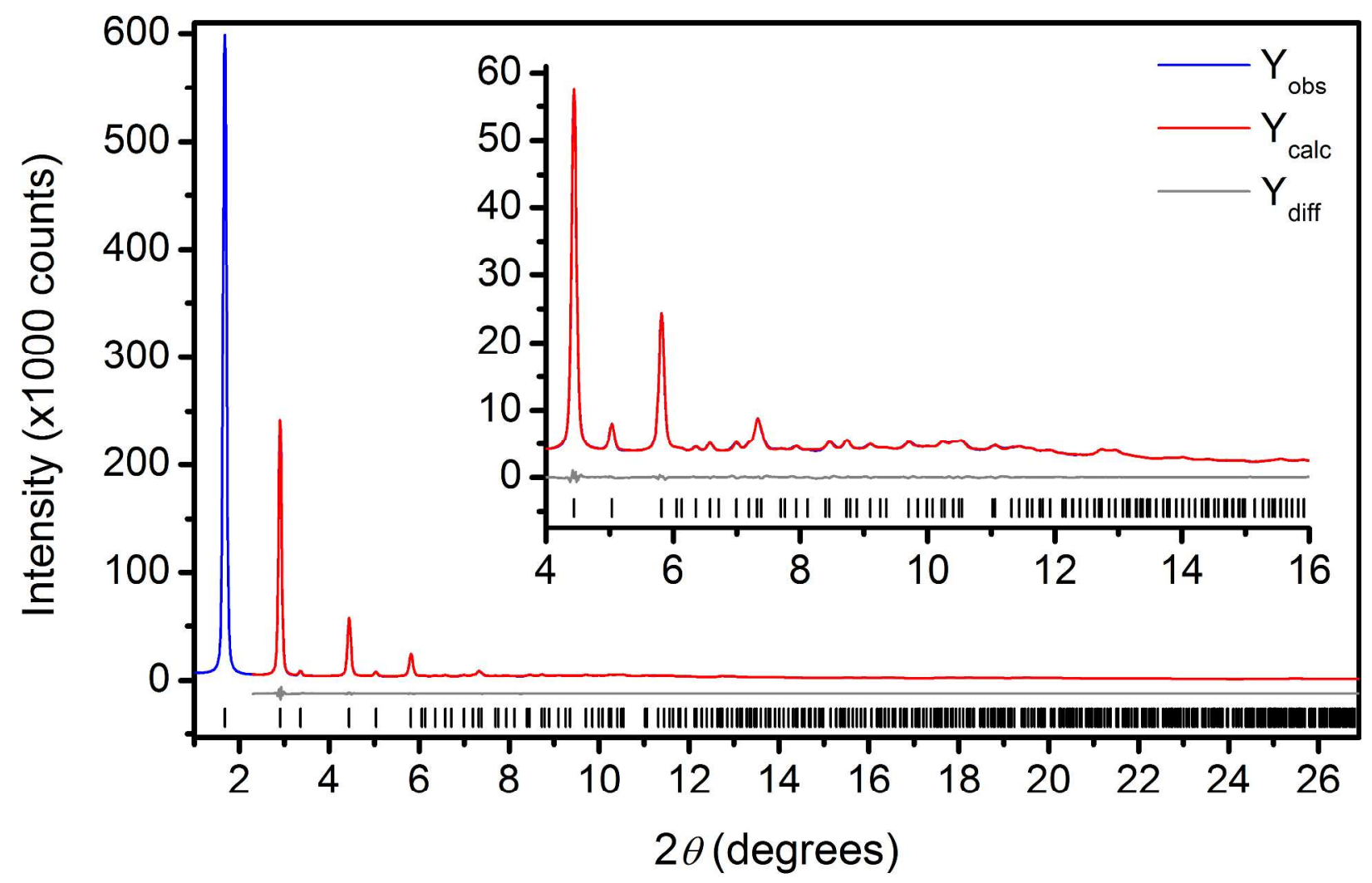

Figure S2. Pawley fit of acetonitrile-solvated $\mathrm{Fe}_{2}\left(\operatorname{dotpdc}^{\mathrm{F}}\right) \cdot 2 \mathrm{CD}_{3} \mathrm{CN}$ from $2.3^{\circ}$ to $27^{\circ}$. The experimental powder pattern of $\mathrm{Fe}_{2}\left(\operatorname{dotpdc}^{\mathrm{F}}\right) \cdot 2 \mathrm{CD}_{3} \mathrm{CN}$ was taken at APS Beamline 17-BM at $298 \mathrm{~K}$ with a wavelength of $0.727680 \AA$. Blue, red, and gray lines represent experimental data, calculated fits, and the difference between the two, respectively; black tick marks represent calculated Bragg peak positions. The inset shows a portion of the high angle region at a magnified scale. The first peak was not refined, as the intensity of the peak was inaccurate due to oversaturation. 


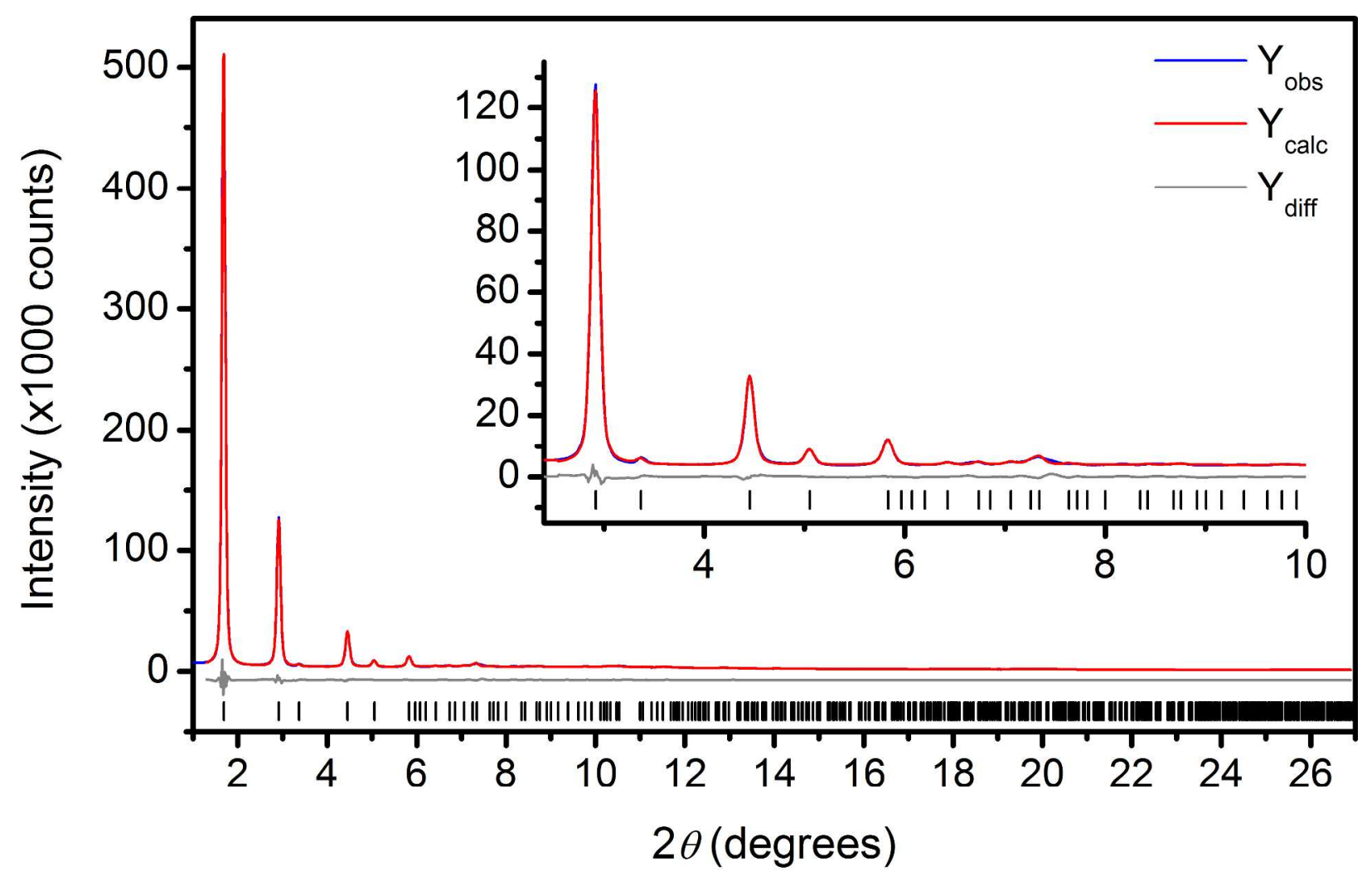

Figure S3. Pawley fit of acetonitrile-solvated $\mathrm{Fe}_{2}\left(\operatorname{dotpdc}{ }^{\mathrm{CH} 3}\right) \cdot 2 \mathrm{CD}_{3} \mathrm{CN}$ from $1.3^{\circ}$ to $27^{\circ}$. The experimental powder pattern of $\mathrm{Fe}_{2}\left(\right.$ dotpdc $\left.^{\mathrm{CH} 3}\right) \cdot 2 \mathrm{CD}_{3} \mathrm{CN}$ was taken at APS Beamline 17-BM at $298 \mathrm{~K}$ with a wavelength of $0.727680 \AA$ A. Blue, red, and gray lines represent experimental data, calculated fits, and the difference between the two, respectively; black tick marks represent calculated Bragg peak positions. The inset shows a portion of the high angle region at a magnified scale. 


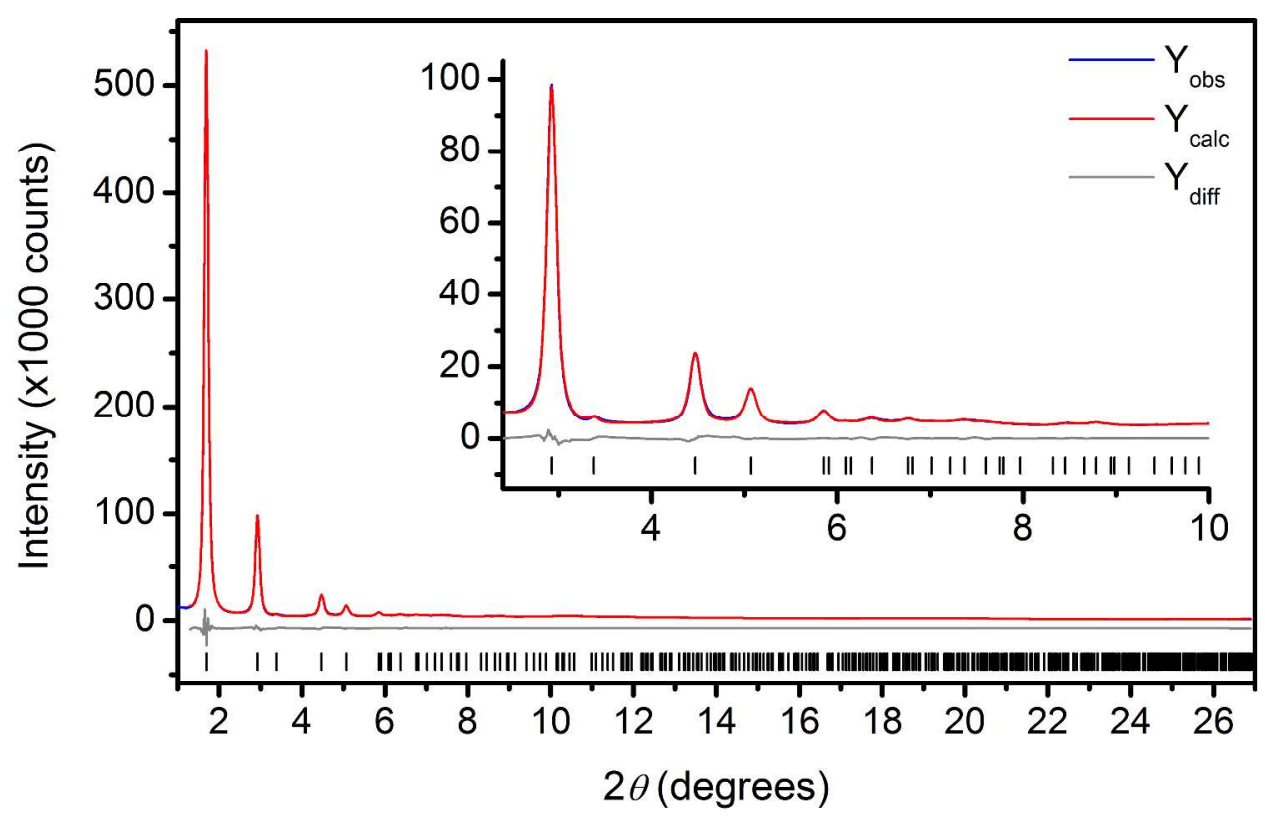

Figure S4. Pawley fit of acetonitrile-solvated $\mathrm{Fe}_{2}\left(\operatorname{dotpdc}^{t \mathrm{Bu}}\right) \cdot 2 \mathrm{CD}_{3} \mathrm{CN}$ from $1.3^{\circ}$ to $27^{\circ}$. The experimental powder pattern of $\mathrm{Fe}_{2}\left(\operatorname{dotpdc}^{\mathrm{t} \mathrm{Bu}}\right)$ was taken at APS Beamline 17-BM at $298 \mathrm{~K}$ with a wavelength of $0.727680 \AA$. Blue, red, and gray lines represent experimental data, calculated fits, and the difference between the two, respectively; black tick marks represent calculated Bragg peak positions. The inset shows a portion of the high angle region at a magnified scale. 

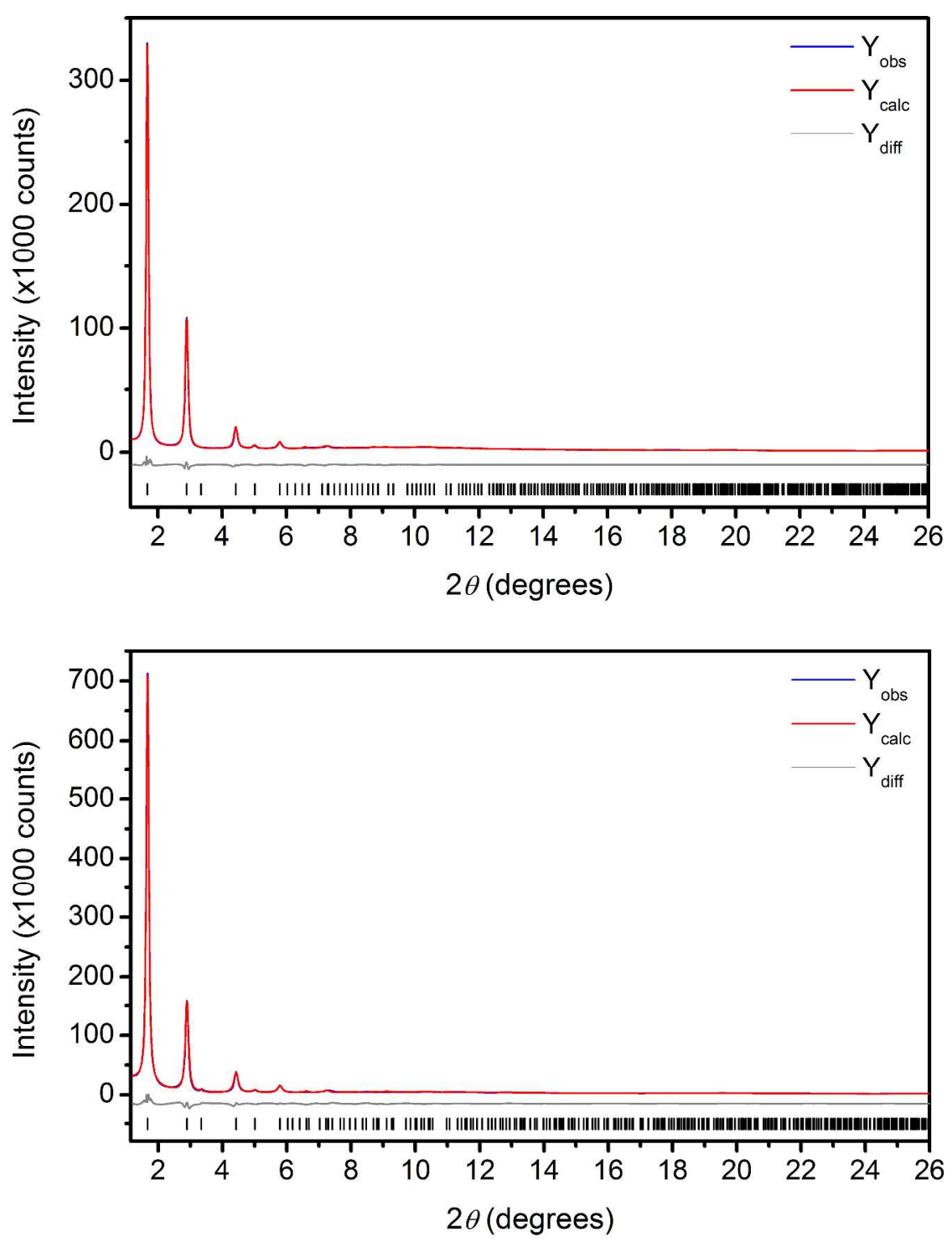

Figure S5. Top: Rietveld refinement of activated $\mathrm{Fe}_{2}$ (dotpdc) at $298 \mathrm{~K}$ from $1.2^{\circ}$ to $26^{\circ}$. Blue and red lines represent the observed and calculated diffraction patterns, respectively. The gray line represents the difference between observed and calculated patterns, and the black tick marks indicate calculated Bragg peak positions. Figures-of-merit (as defined by TOPAS): $R_{\mathrm{wp}}=3.76 \%$, $R_{\mathrm{p}}=3.76 \%, R_{\mathrm{Bragg}}=1.41 \%, \mathrm{GoF}=2.66$. The wavelength was $0.727680 \AA$.

Bottom: Rietveld refinement of activated $\mathrm{Fe}_{2}\left(\operatorname{dotpdc}^{\mathrm{F}}\right)$ at $298 \mathrm{~K}$ from $1.2^{\circ}$ to $26^{\circ}$. Blue and red lines represent the observed and calculated diffraction patterns, respectively. The gray line represents the difference between observed and calculated patterns, and the black tick marks indicate calculated Bragg peak positions. Figures-of-merit (as defined by TOPAS): $R_{\mathrm{wp}}=6.34 \%$, $R_{\mathrm{p}}=6.83 \%, R_{\mathrm{Bragg}}=2.59 \%, \mathrm{GoF}=6.12$. The wavelength was $0.727680 \AA$. 


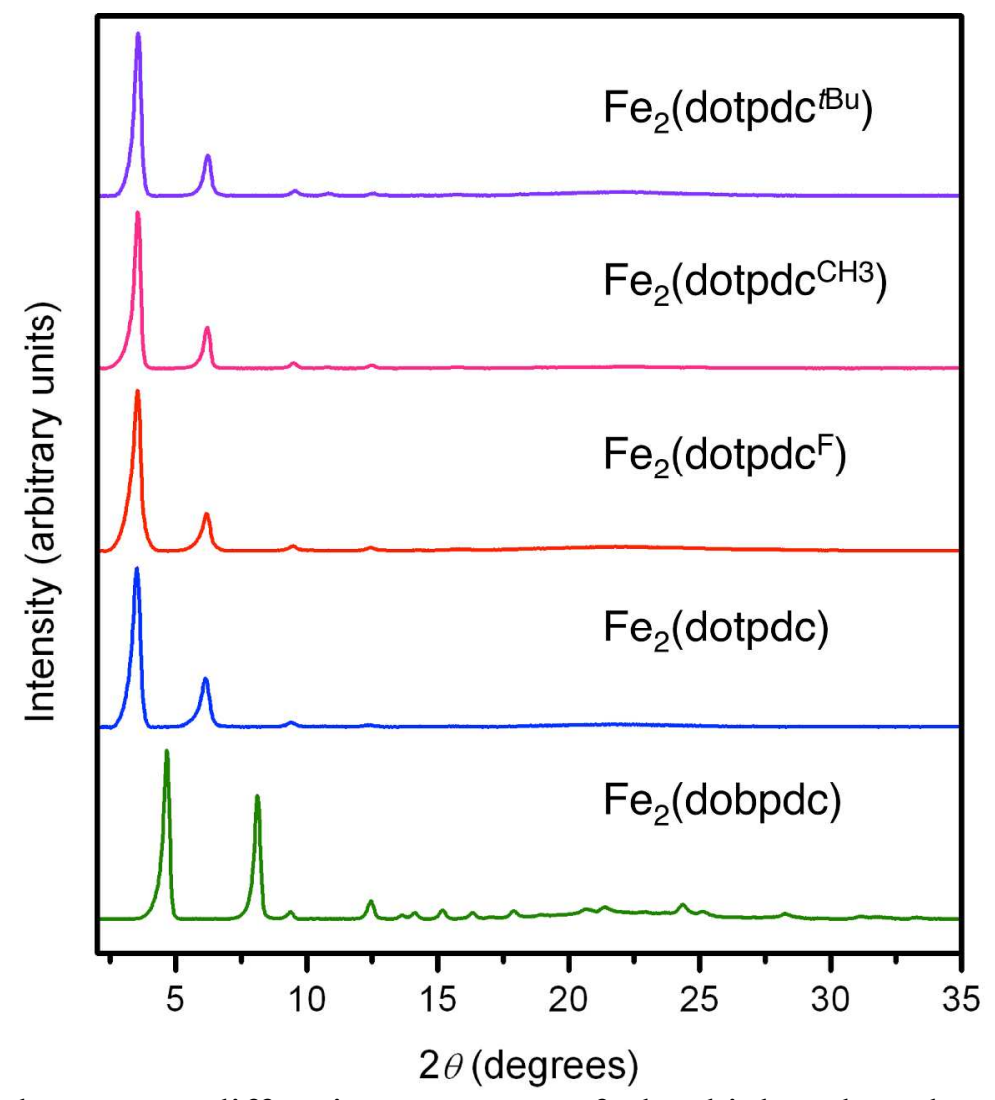

Figure S6. Powder X-ray diffraction patterns of the biphenyl and terphenyl $\mathrm{Fe}_{2}$ (dobdc) analogues after a catalytic cyclohexane oxidation run. While the frameworks change color from yellow/green to red brown, indicative of oxidation of the $\mathrm{Fe}$ (II) centers to $\mathrm{Fe}(\mathrm{III})$, no loss in crystallinity is observed. The wavelength was $1.5418 \AA$. 


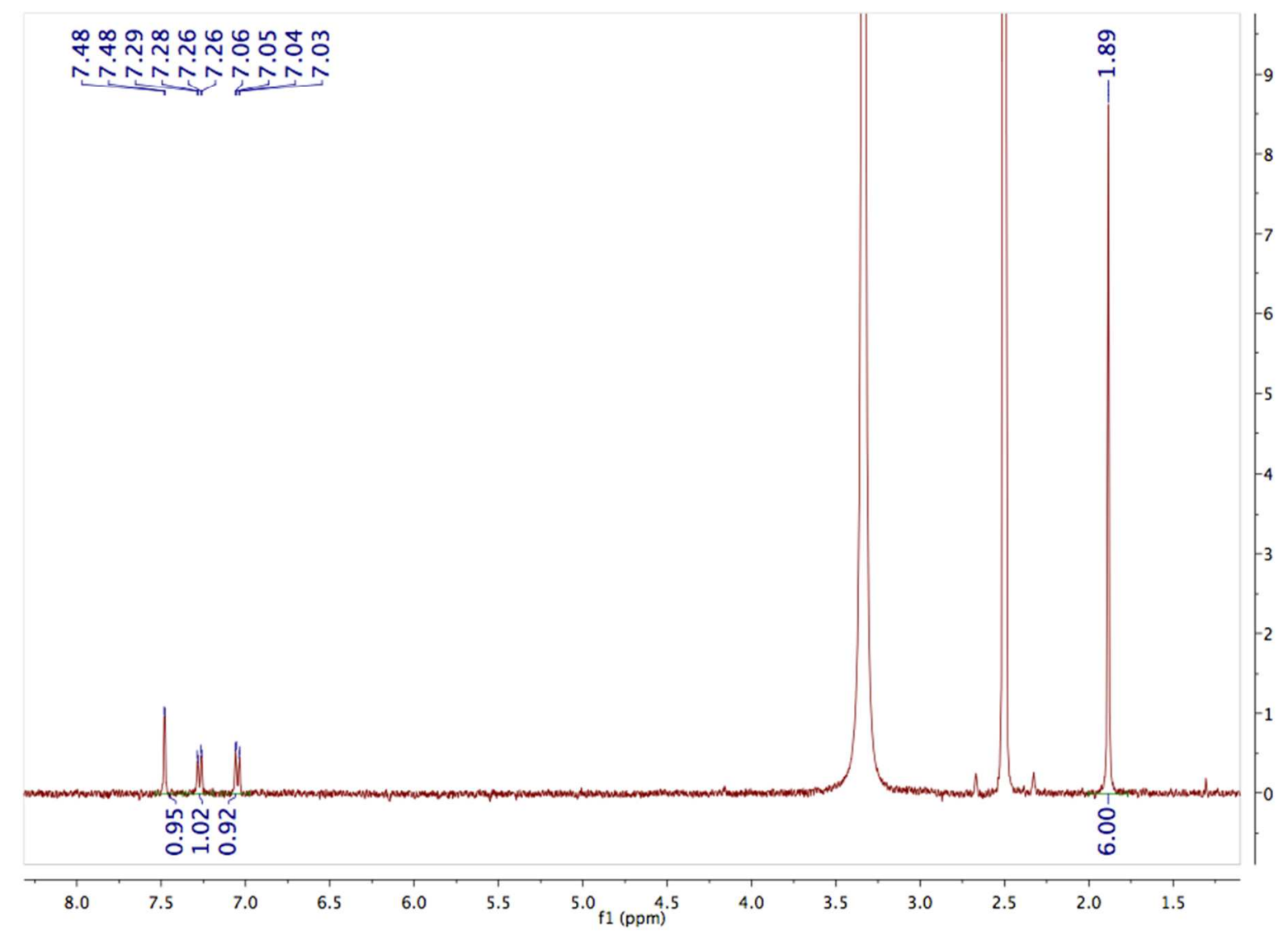

Figure S7. ${ }^{1} \mathrm{H}$ NMR of $\mathrm{H}_{4}\left(\operatorname{dotpdc}^{\mathrm{CH} 3}\right)$ post-catalysis $\left(\mathrm{DMSO}-\mathrm{d}_{6}\right)$. Acid digestion of $\mathrm{Fe}_{2}\left(\right.$ dotpdc $\left.^{\mathrm{CH} 3}\right)$ and ${ }^{1} \mathrm{H}$ NMR analysis of the ligand after a cyclohexane oxidation run suggests that the ligand is not hydroxylated or otherwise oxidized over the course of the reaction. 


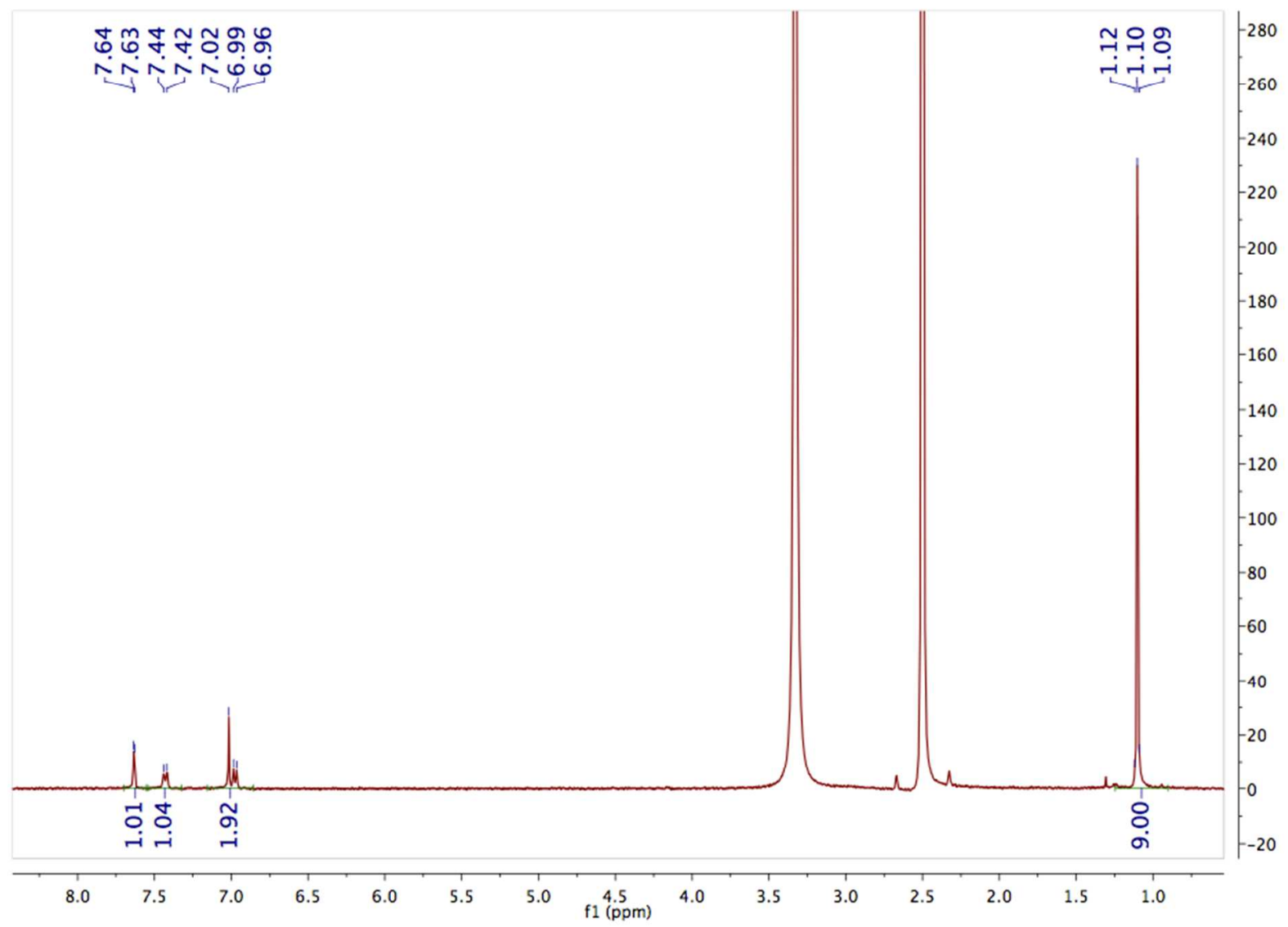

Figure S8. ${ }^{1} \mathrm{H}$ NMR of $\mathrm{H}_{4}\left(\operatorname{dotpdc}^{t \mathrm{Bu}}\right)$ post-catalysis $\left(\right.$ DMSO- $\left.\mathrm{d}_{6}\right)$. Acid digestion of $\mathrm{Fe}_{2}\left(\operatorname{dotpdc}^{t \mathrm{Bu}}\right)$ and ${ }^{1} \mathrm{H} \mathrm{NMR}$ analysis of the ligand after a cyclohexane oxidation run suggests that the ligand is not hydroxylated or otherwise oxidized over the course of the reaction. 

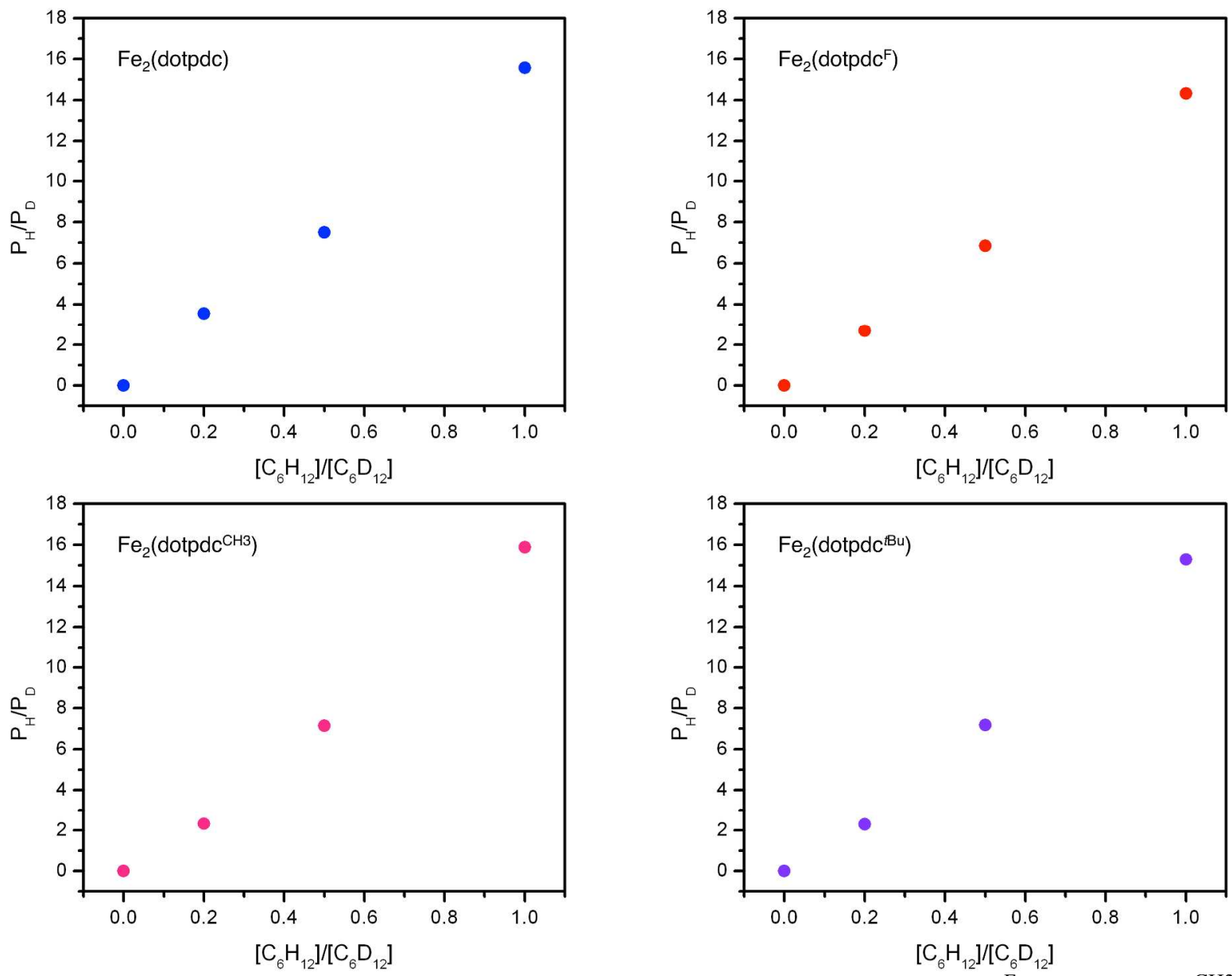

Figure S9. Kinetic isotope effect determination for $\mathrm{Fe}_{2}(\operatorname{dotpdc}), \mathrm{Fe}_{2}\left(\operatorname{dotpdc}^{\mathrm{F}}\right), \mathrm{Fe}_{2}\left(\operatorname{dotpdc}^{\mathrm{CH} 3}\right)$, and $\mathrm{Fe}_{2}\left(\operatorname{dotpdc}^{t \mathrm{Bu}}\right)$. The ratio of protio to deuterated products, $\left[P_{\mathrm{H}}\right] /\left[P_{\mathrm{D}}\right]$, was plotted versus the initial $\left[\mathrm{C}_{6} \mathrm{H}_{12}\right] /\left[\mathrm{C}_{6} \mathrm{D}_{12}\right]$ ratio. The slope obtained from fitting these points to a line is the KIE, which was determined to be $15.4(5), 14.4(2), 16.1(8)$, and $15.5(6)$ for $\mathrm{R}=\mathrm{H}, \mathrm{F}, \mathrm{CH} 3$, and $t \mathrm{Bu}$, respectively. 


\section{References.}

(1) Song, F.; Wang, C.; Falkowski, J. M.; Ma, L.; Lin, W. J. Am. Chem. Soc. 2010, 132, 15390-15398.

(2) Bloch, E. D.; Murray, L. J.; Queen, W. L.; Chavan, S.; Maximoff, S. N.; Bigi, J. P.; Krishna, R.; Peterson, V. K.; Grandjean, F.; Long, G. J.; Smit, B.; Bordiga, S.; Brown, C. M.; Long, J. R. J. Am. Chem. Soc. 2011, 133, 14814-14822.

(3) McDonald, T. M.; Mason, J. A.; Kong, X.; Bloch, E. D.; Gygi, D.; Dani, A.; Crocella, V.; Giordanino, F.; Odoh, S. O.; Drisdell, W. S.; Vlaisavljevich, B.; Dzubak, A. L.; Poloni, R.; Schnell, S. K.; Planas, N.; Lee, K.; Pascal, T.; Wan, L. F.; Prendergast, D.; Neaton, J. B.; Smit, B.; Kortright, J. B.; Gagliardi, L.; Bordiga, S.; Reimer, J. A.; Long, J. R. Nature 2015, 519, 303- 308 .

(4) Mo, F.; Yan, J. M.; Q. D.; Li, F.; Zhang, Y.; Wang, J. Angew. Chem. Int. Ed. 2010, 49, 2028.

(5) Tajuddin, H.; Harrisson, P.; Bitterlich, B.; Collings, J. C.; Sim, N.; Batsanov, A. S.; Cheung, M. S.; Kawamorita, S.; Maxwell, A. C.; Shukla, L.; Morris, J.; Lin, Z.; Marder, T. B.; Steel, P. G. Chem. Sci. 2012, 3, 3505.

(6) Ion Prisecaru, WMOSS4 Mössbauer Spectral Analysis Software, www.wmoss.org, 20092013. 